\title{
Productivity and nutrient use efficiency with integrated fertilization of buckwheat-fenugreek intercrops
}

\author{
Aliyeh Salehi • Bano Mehdi $(\mathbb{D} \cdot$ Sina Fallah $\cdot$ Hans-Peter Kaul $\mathbb{D} \cdot$ \\ Reinhard W. Neugschwandtner $\mathbb{D}$
}

Received: 21 June 2017 / Accepted: 8 January 2018/Published online: 31 January 2018

(C) The Author(s) 2018. This article is an open access publication

\begin{abstract}
Intercrops and organic fertilizers can improve the productivity of cropping systems due to increased soil nutrient availability and plant nutrient use efficiency. A 2-year field experiment was conducted to determine the effects of different intercropping ratios and fertilizer types on nitrogen $(\mathrm{N})$ and phosphorus $(\mathrm{P})$ concentrations and yields of fenugreek and buckwheat at the research farm of Shahrekord University, Iran. The treatments consisted of sole cropping of fenugreek (F), buckwheat (B) and three intercropping ratios $(\mathrm{F}: \mathrm{B}=1: 2,1: 1$ and $2: 1)$ under three fertilizer types: chemical fertilizer $(\mathrm{CF})$, integrated fertilizer (IF) and broiler litter (BL). At flowering and at harvest, intercropping increased total above-ground dry matter (TAGDM), total seed yield, $\mathrm{N}$ and $\mathrm{P}$ concentrations (plant) and uptake. The
\end{abstract}

Electronic supplementary material The online version of this article (https://doi.org/10.1007/s10705-018-9906-x) contains supplementary material, which is available to authorized users.

\section{A. Salehi · S. Fallah}

Faculty of Agriculture, Shahrekord University,

Shahrekord, Iran

\section{A. Salehi $(\bowtie) \cdot$ B. Mehdi · H.-P. Kaul •}

R. W. Neugschwandtner

Division of Agronomy, Department of Crop Sciences,

University of Natural Resources and Life Sciences,

Vienna (BOKU), Konrad Lorenz-Straße 24, 3430 Tulln,

Austria

e-mail: aliyeh.salehi@boku.ac.at applied $\mathrm{N}$ use efficiency and applied $\mathrm{N}$ recovery efficiency (ANUE, ANRE) in the intercropped plots were also higher as compared to the sole cropping. The intercropping ratio of F:B $(2: 1)$ was the most suitable for improving the tested nutrient variables. The IF and BL showed significant benefits as compared to $\mathrm{CF}$, for TAGDM, total seed yield, $\mathrm{N}_{\mathrm{C}}$ and $\mathrm{P}_{\mathrm{C}}$ in the plant, as well as $\mathrm{N}$ and $\mathrm{P}$ uptake in sole and intercrops. For ANUE and ANRE, CF proved to be more effective. This study showed that a 2:1 fenugreek-buckwheat intercropped system with the application of IF and BL can successfully be implemented for improving productivity, $\mathrm{N}$ and $\mathrm{P}$ contents of fenugreek and buckwheat as well as the nutrient land equivalent ratio (compared with sole cropping with $\mathrm{CF}$ ) under semiarid growing conditions.

Keywords Cropping system · Fenugreek ·

Buckwheat $\cdot$ Broiler litter $\cdot$ Macronutrients $\cdot$ Nutrient land equivalent ratio

\section{Introduction}

Best agricultural management practices implemented in agricultural production systems can help to achieve efficient crop nutrient use as well as improve crop diversity in the landscape. For example, intercropping (with or without legumes), fertilizer management, 
crop rotations and reduced tillage practices can lead to lower external inputs, efficient crop nutrient use and yield improvements (Scalise et al. 2015; Dahmardeh and Hodiani 2016; Jouzi et al. 2017). Benefits for the soil can also be realized through improved biological and chemical characteristics (Oelbermann and Echarte 2011; Chapagain and Riseman 2014).

Intercropping is a widespread practice that has been successfully performed in most parts of the world, including Southeast Asia, Latin America, Africa, China, India (Yan et al. 2014) and in tropical regions (Dhima et al. 2007) and is also becoming more common in Europe (Hauggaard-Nielsen et al. 2009b). Typical species used in intercropping systems include legumes such as clover (Trifolium), vetch (Vicia), beans (Phaseolus vulgaris) and peas (Pisum sativum) and non-legumes such as barley (Hordeum vulgare), buckwheat (Fagopyrum esculentum), rye (Secale cereale), oat (Avena sativa), wheat (Triticum) and flax (Linum usitatissimum) (Chapagain and Riseman 2014; Hamzei and Seyyedi 2016). Intercropping with legumes can particularly enhance soil fertility by increasing soil nitrogen $(\mathrm{N})$ through the $\mathrm{N}$-fixing ability of rhizobacteria, thereby allowing more fixed$\mathrm{N}$ to remain in the upper soil layers and be plant available (Hauggaard-Nielsen et al. 2009a; Chapagain and Riseman 2014). Intercropping has been found to increase the use of available N (Bedoussac and Justes 2010) as well as macro- and micronutrients in crops (Neugschwandtner and Kaul 2016). Consequently, the nutrient use efficiency can be improved and fertilizer requirements of the main crops can be reduced compared with regular non-intercropped crop stands (Ghosh et al. 2009; Rostaei et al. 2014). Sahota and Malhi (2012) showed that the LER from barley + pea intercropping was 1.3 as compared to sole crop of barley.

A relatively new intercropping system is a cereal intercropped with a leguminous medicinal plant, such as fenugreek (Trigonella foenum-graecum L.), which possesses multiple uses for food, feed and health. Medicinal plants, such as fenugreek, not only provide an important contribution to human health, they also can improve the soil fertility by increasing $\mathrm{N}$ available for plant uptake through biological fixation (Dadrasan et al. 2015). Furthermore, medicinal plants can also provide an interesting source of alternative income for farmers especially on marginal lands, for example, Dai et al. (2013) demonstrated that peanut (Arachis hypogaea) intercropped with the medicinal plant Atractylodes (Atractylodes lancea) increased peanut yields and also increased the incomes of some farmers because the Atractylodes were more valuable as compared to traditional agricultural crops in the subtropical China.

Fenugreek is an annual legume and one of the oldest medicinal plants from the Fabacea family; it is native to Eastern Europe to Central Asia (Kenny et al. 2013; Ahmad et al. 2016). It is cultivated widely in Africa, India and the United States of America for food, feed and for the substantial medicinal values of its seeds (Ahmad et al. 2016). For example, consuming fenugreek has been correlated with many positive health benefits related to improving hyperglycaemia (Ruby et al. 2005) and diabetes (Saxena and Vikram 2004).

Medicinal plants as intercrops are gaining interest in both developing and developed countries and can provide a novel strategy for sustainable agricultural cropping systems (Chandrashekara and Somashekarappa 2016).

The common buckwheat (Fagopyrum esculentum Moench) from the family Polygonaceae can be intercropped with fenugreek and also shows healthpromoting benefits, specifically with regards to vitamins, proteins, minerals, antioxidants, flavonoids (rutin, catechins) and dietary fibre. These properties have helped to keep demands for buckwheat high (Alamprese et al. 2007).

Studies have shown that use of organic manures has several benefits over chemical fertilizers, for example they improve soil phosphorus (P) availability, in particular the $\mathrm{P}$ adsorption and desorption amounts, and consequently increase the $\mathrm{P}$ recovery by the crops as compared to chemical fertilizers (Iyamuremye and Dick 1996). The application of organic fertilizers in a groundnut (Arachis hypogaea)-corn intercropping system showed significant positive effects on the crop $\mathrm{P}$ concentration, $\mathrm{P}$ uptake, biomass and also soil residual nutrients as compared to chemical fertilizers (Mohanty et al. 2006). Moreover, the applications of organic manures can be a valuable resource to replenish the organic matter content in most soils (Damodar Reddy et al. 2000). However, a growing livestock industry as well as the large amounts of livestock waste increasingly applied to arable land can lead to a surplus of $\mathrm{N}$ and $\mathrm{P}$ applied to agricultural fields (Yan et al. 2013). By applying high amounts of 
manure, the soil inorganic $\mathrm{P}$, the $\mathrm{P}$ saturation ratio and phosphates can significantly be increased (Yan et al. 2016). One strategy for maintaining soil quality and fertility, including the adequate application of crop nutrients, is through the application of integrated fertilizers, e.g. combined animal manure with chemical fertilizers (Alizadeh et al. 2012).

Integrated fertilizers have several benefits, for example integrating chemical fertilizer with liquid pig manure was shown to supply a valuable nutrient source for wheat production with improved $\mathrm{N}$ nutrition (Meade et al. 2011). A significantly higher wheat and soybean yield and $\mathrm{P}$ uptake through the application of integrated fertilizer (cattle manure and chemical P) as compared to their sole application was reported by Damodar Reddy et al. (2000). He et al. (2015) showed that applying chemical fertilizer plus manure (horse manure, pig manure, and cattle manure) contributed to higher $\mathrm{C}$ and $\mathrm{N}$ inputs and increased the biomass of roots due to improved crop growth. Thus, the intercropping system and the fertilizer type affect the availability of $\mathrm{N}$ and $\mathrm{P}$ for the plant as well as the nutrient use efficiency. For a fenugreek-buckwheat intercropped system little information on the $\mathrm{N}$ and $\mathrm{P}$ content of the plant and seeds is available with the application of organic and chemical fertilizers. Hence, the objectives of this study were to: (1) compare the application of different fertilizer types on the $\mathrm{N}$ and $\mathrm{P}$ concentration and yield of fenugreek and buckwheat, (2) quantify the $\mathrm{N}$ and $\mathrm{P}$ uptake of the sole and intercropped plants, (3) compare biomass and seed production of the sole and intercrops plants and (4) calculate any competitive nutrient land equivalent ratios of intercropped fenugreek and buckwheat.

\section{Materials and methods}

\section{Experimental site}

A field experiment was established at the research farm of Shahrekord University $\left(32^{\circ} 21^{\prime} \mathrm{N}, 50^{\circ} 49^{\prime} \mathrm{E}\right.$; $2050 \mathrm{~m}$ a.s.1.), Iran, in 2014 and 2015. The research farm is characterized by an average annual mean temperature of $10.5^{\circ} \mathrm{C}$ and average annual rainfall of $280 \mathrm{~mm}$. The soil texture is a clay loam and the soil type is a fine, carbonatic, mesic Calcixerept.

A two-factorial experiment in a randomized complete block design was conducted with three replications. The first factor was the cropping system with 5 levels: sole cropping of fenugreek $(\mathrm{F})$, sole cropping of buckwheat (B) and three substitutive row intercropping ratios: $\mathrm{F}: \mathrm{B}=1: 2$ (one row of fenugreek + two rows of buckwheat), 1:1 (one row of fenugreek + one row of buckwheat) and 2:1 (two rows of fenugreek + one row of buckwheat). The second factor was the $\mathrm{N}$ fertilizer type with 3 levels: chemical fertilizer (CF), broiler litter (BL) and integrated fertilizer ( $\mathrm{IF}=50 \% \mathrm{CF}+50 \% \mathrm{BL}$ ). Thus, the field experiment consisted of 45 plots in two nearby sites A and B in 2014 and 2015, respectively (Fig. 1S).

Individual experimental plots had an area of $7.5 \mathrm{~m}^{2}$ $(2.5 \times 3 \mathrm{~m})$ and comprised 10 rows with $0.25 \mathrm{~m}$ spacing. To avoid contamination by the seepage of irrigation water from adjacent plots, a distance of $1.5 \mathrm{~m}$ between plots and between blocks was kept. The amount of $\mathrm{N}$ applied to fenugreek and buckwheat was 80 and $60 \mathrm{~kg} \mathrm{~N} \mathrm{ha}^{-1}$, respectively, according to local farmers' practices. The application of 10 and $7.5 \mathrm{Mg} \mathrm{ha}^{-1}$ of broiler litter provided the 80 and $60 \mathrm{~kg} \mathrm{~N} \mathrm{ha}^{-1}$, respectively, assuming $50 \%$ of mineralization of broiler litter $\mathrm{N}$ during the first cropping season as observed earlier in the study region by Alizadeh et al. (2012). Intercrops received equivalent fertilizer amounts according to their species composition. After soil tillage with a moldboard plough on May 1, 2014 and April 24, 2015, the broiler litter was applied by hand. In the chemical fertilizer treatments, urea was applied with one-third of the total rate applied at planting and two-thirds applied 30 days after planting. Phosphorus (P) was applied as triple superphosphate, and $\mathrm{Fe}, \mathrm{Mn}, \mathrm{Cu}$, and $\mathrm{Zn}$ were applied to the urea-fertilized plots at a rate equivalent to the total amounts added by the broiler litter treatments in order to compensate for the nutrient inputs of these elements with the organic fertilizer. In the integrated fertilizer treatments, $50 \%$ of chemical fertilizer and $50 \%$ of broiler litter was applied to each plot.

Seeds of fenugreek (Isfahan landrace) and buckwheat were provided by Pakan Bazr, Iran and Rudloff Feldsaaten, Germany, respectively. The crops were sown by hand on May 29, 2014 and on May 23, 2015. Fenugreek and buckwheat were sown at 50 and 120 plants $\mathrm{m}^{-2}$ at a depth of $0.01-0.02$ and 0.02-0.04 m, respectively, both in the sole and in the intercropped plots. In each planting hole, three seeds of fenugreek or buckwheat were sown. To obtain the required plant densities, fenugreek and buckwheat 
seedlings were thinned at the 3-4 leaf stage. The experimental plots were irrigated at 6-day intervals. Mechanical hand weeding was performed.

Sampling and measurements

\section{Soil and nutrient sampling}

Before sowing, composite soil samples were taken at $0-0.3 \mathrm{~m}$ depth from the experimental field for chemical analysis in both years. The broiler litter was also analysed to determine the nutrient characteristics in 2014 and 2015 (Table 1S).

\section{Plant analysis}

Each year, the dry biomass was determined during the flowering stage of fenugreek and buckwheat plants. The plant samples were oven-dried at $70{ }^{\circ} \mathrm{C}$ for $48 \mathrm{~h}$ to obtain a constant dry weight and the samples were subsequently powdered by a miller. The above-ground dry matter of the individual plant species $\left(\mathrm{AGDM}_{\mathrm{P}}\right)$ in $\mathrm{kg} \mathrm{ha}^{-1}$ was calculated by taking the oven dry weight of only fenugreek or only of buckwheat and calculating the weight on a per ha basis.

Furthermore, the total above-ground dry matter at the flowering stage of all plants (TAGDM) in $\mathrm{kg} \mathrm{ha}^{-1}$ was calculated by adding the $\mathrm{AGDM}_{\mathrm{P}}$ of fenugreek and of buckwheat.

\section{Seed analysis}

Each year, the plants were harvested manually to determine the macronutrient content of seeds. Samples of 20 plants for each crop were sampled by cutting the plant at the base at full maturity; for buckwheat on September 6, 2014 and September 1, 2015 and for fenugreek on September 12, 2014 and September 15, 2015. Thereafter, seeds were separated from plants and oven-dried at $70{ }^{\circ} \mathrm{C}$ for $48 \mathrm{~h}$ to obtain a constant weight. The sample of seeds from each plot was ground by using a grinding mill. The total seed yield in $\mathrm{kg} \mathrm{ha}^{-1}$ was calculated by adding the seed yield of fenugreek with the seed yield of buckwheat.
Determination of $\mathrm{N}$ and $\mathrm{P}$ concentrations and uptake

To determine the $\mathrm{N}$ concentration $\left(\mathrm{N}_{\mathrm{C}}\right)$, milled samples of the plants (at flowering stage) and seeds (after harvesting) were digested using the Kjeldahl method (Bremner 1996). To determine the P concentration $\left(\mathrm{P}_{\mathrm{C}}\right)$, the spectrophotometric method (Jackson 1958) was used. The $\mathrm{N}$ uptake $\left(\mathrm{N}_{\mathrm{Up}}\right)$ and $\mathrm{P}$ uptake $\left(\mathrm{P}_{\mathrm{Up}}\right)$ were calculated for each crop at the flowering stage and also for the seeds by multiplying the $\mathrm{AGDM}_{\mathrm{P}}$ and the seed yield with both the $\mathrm{Nc}$ and Pc, respectively. The total $\mathrm{N}$ uptake in seeds $\left(\mathrm{TN}_{\mathrm{Up}}\right)$ in $\mathrm{kg} \mathrm{ha}^{-1}$ was calculated by adding the $\mathrm{N}_{\mathrm{Up}}$ of fenugreek with the $\mathrm{N}_{U p}$ of buckwheat in the seed. Likewise, the total $\mathrm{P}$ uptake in seeds $\left(\mathrm{TP}_{\mathrm{Up}}\right)$ in $\mathrm{kg} \mathrm{ha}^{-1}$ was calculated by adding the $\mathrm{P}_{\mathrm{Up}}$ of fenugreek with the $\mathrm{P}_{\mathrm{Up}}$ of buckwheat in the seed.

Determination of the nutrient land equivalent ratio

The nutrient land equivalent ratio for nitrogen $(\mathrm{N}-$ LER) and phosphorus (P-LER) in the total aboveground dry matter (TAGDM) and for the seed yield were calculated. The land equivalent ratio considers the yield ratios to indicate the amount of land required to grow sole crops of each as compared to the amount of land required to grow both crops as intercrops. This concept can be applied to nutrients such as $\mathrm{N}$ and $\mathrm{P}$ to determine the nutritional advantage of intercropping. The nutrient LER was determined for each treatment at the flowering stage and for the seed yield according to Mead and Willey (1980) as follows:

$$
\begin{aligned}
& \mathrm{N}-\text { LER }=\frac{\text { NupYfb }}{\text { NupYff }}+\frac{\text { NupYbf }}{\text { NupYbb }} \\
& \mathrm{P}-\text { LER }=\frac{\text { PupYfb }}{\text { PupYff }}+\frac{\text { PupYbf }}{\text { PupYbb }}
\end{aligned}
$$

where $N_{\text {up }}$ is the nitrogen uptake of the plant or the seed, $\mathrm{P}_{\text {up }}$ is the phosphorus uptake of the plant or the seed, Yff is the yield of fenugreek in the sole plots, $\mathrm{Ybb}$ is the yield of buckwheat in the sole plots, $\mathrm{Yfb}$ is the yield of the fenugreek in the intercropped plots, and $\mathrm{Ybf}$ is the yield of buckwheat in the intercropped plots.

The nutrient LER is the summation of the partial nutrient LERs of the single crops in the intercropped system. Partial nutrient LERs show the relative 
competitive abilities of single crops in intercropping (Neugschwandtner and Kaul 2014). A nutrient LER $>1$ indicates a nutritional advantage while a nutrient LER $<1$ indicates a disadvantage of the intercropping system.

Determination of applied $\mathrm{N}$ use and $\mathrm{N}$ recovery efficiency

The applied $\mathrm{N}$ use efficiency (ANUE) in the seeds and the applied $\mathrm{N}$ recovery efficiency (ANRE) were calculated as follows:

$\operatorname{ANUE}\left(\mathrm{kg} \mathrm{kg}^{-1}\right)=\mathrm{Y} / \mathrm{N}_{\mathrm{Ap}}$

$\operatorname{ANRE}(\%)=\mathrm{N}_{\mathrm{Up}} / \mathrm{N}_{\mathrm{Ap}}$

where $\mathrm{Y}$ is total seed yield, $\mathrm{N}_{\mathrm{Ap}}$ is the total applied $\mathrm{N}$ and $\mathrm{N}_{\mathrm{Up}}$ is the total $\mathrm{N}$ uptake from the seeds of fenugreek and buckwheat. For both the ANUE and the ANRE, the total amount of applied N in BL and IF were taken in consideration (not just the assumed mineralized 50\%, CF. Chapter 2.1.).

\section{Statistical analysis}

An analysis of variance (PROC ANOVA) using SAS version 9.2 for two factorial experiments was performed on data from each year considering intercropping ratio as the first factor and fertilizer type as the second factor. Means were separated by least significant differences (LSD) when the F-test indicated factorial effects at the significance level $p<0.05$. The significance of the relationships between $\mathrm{N}$ and $\mathrm{P}$ concentrations, uptake and production $\left(\mathrm{AGDM}_{\mathrm{P}}\right.$ and seed yield) at the flowering stage and at maturity was determined using the Pearson correlation coefficient (Tables 1, 2 in Appendix).

\section{Results}

Above-ground dry matter $\left(\mathrm{AGDM}_{\mathrm{P}}\right)$

In both years, a significant effect of intercropping and fertilizer type was found on the $\mathrm{AGDM}_{\mathrm{P}}$ of fenugreek and buckwheat at the flowering stage (Fig. 1a-d). The fenugreek $\mathrm{AGDM}_{P}$ was highest in the sole fenugreek treatment and decreased with increasing rows of buckwheat (Fig. 1a, b). Furthermore, the AGDM $_{P}$ was mostly higher in the IF and BL fertilized treatments, compared with the chemical fertilizer treatment (CF). In 2014, when IF and BL were applied, the sole fenugreek plots had significantly higher $\mathrm{AGDM}_{\mathrm{P}}$, on an average by $27 \%$ as compared to the CF (Fig. 1a). This trend was also observed in the intercropped plots, where the $\mathrm{AGDM}_{P}$ was significantly higher by $22 \%$ in the IF and BL treatments. In 2015, in the sole plots, the $\mathrm{AGDM}_{\mathrm{P}}$ was significantly higher by $16 \%$ in the BL treatment compared with the $\mathrm{CF}$ treatment (Fig. 1b). In the intercropped treatments, no significant $\mathrm{AGDM}_{\mathrm{P}}$ differences were found, except for the BL treatment in the fenugreek: buckwheat (1:2) treatment, which had lower $\mathrm{AGDM}_{\mathrm{P}}$ by $16 \%$ (Fig. 1a, b).

For buckwheat, in both years, the $\mathrm{AGDM}_{\mathrm{P}}$ of buckwheat was highest in the sole buckwheat plots and decreased with increasing share of fenugreek (Fig. 1c, d). Once more, the $\mathrm{AGDM}_{\mathrm{P}}$ was higher in the IF and BL fertilized treatments, compared with the CF fertilizer treatment, except at the fenugreek: buckwheat (1:1 and 2:1) treatments in 2014 (Fig. 1c). When IF and BL were applied, the buckwheat $\mathrm{AGDM}_{\mathrm{P}}$ in the sole plots was significantly higher, on an average by 55\% (2014) and 56\% (2015) as compared to the CF. Also in 2015 in the intercropped plots, the $\mathrm{AGDM}_{\mathrm{P}}$ was significantly higher by $40 \%$ average in both IF and BL treatments (Fig. 1d).

\section{Seed yield}

In both years, the seed yield of both fenugreek and buckwheat was significantly affected by intercropping and fertilizer type (Fig. 1e-h). For fenugreek, the seed yield was highest in the sole fenugreek plots and decreased with increasing share of buckwheat (Fig. 1e, f). In 2015, the highest seed yield of fenugreek was found in the IF and BL treatments (on an average higher by 27\%) as compared to $\mathrm{CF}$ treatments (Fig. 1f).

For buckwheat, the seed yield was highest in the sole plots and increased with increasing share of fenugreek in intercropped plots in 2015 (Fig. 1g, h). The sole plots fertilized with IF and BL had a higher seed yield on an average by $46 \%$ (2014) and $21 \%$ (2015) than the CF treatments. In 2014, a higher seed yield was observed in the IF and BL fertilized fenugreek: buckwheat (2:1) plots by $42 \%$ average as compared to CF treatment (Fig. 1g). In 2015, the 


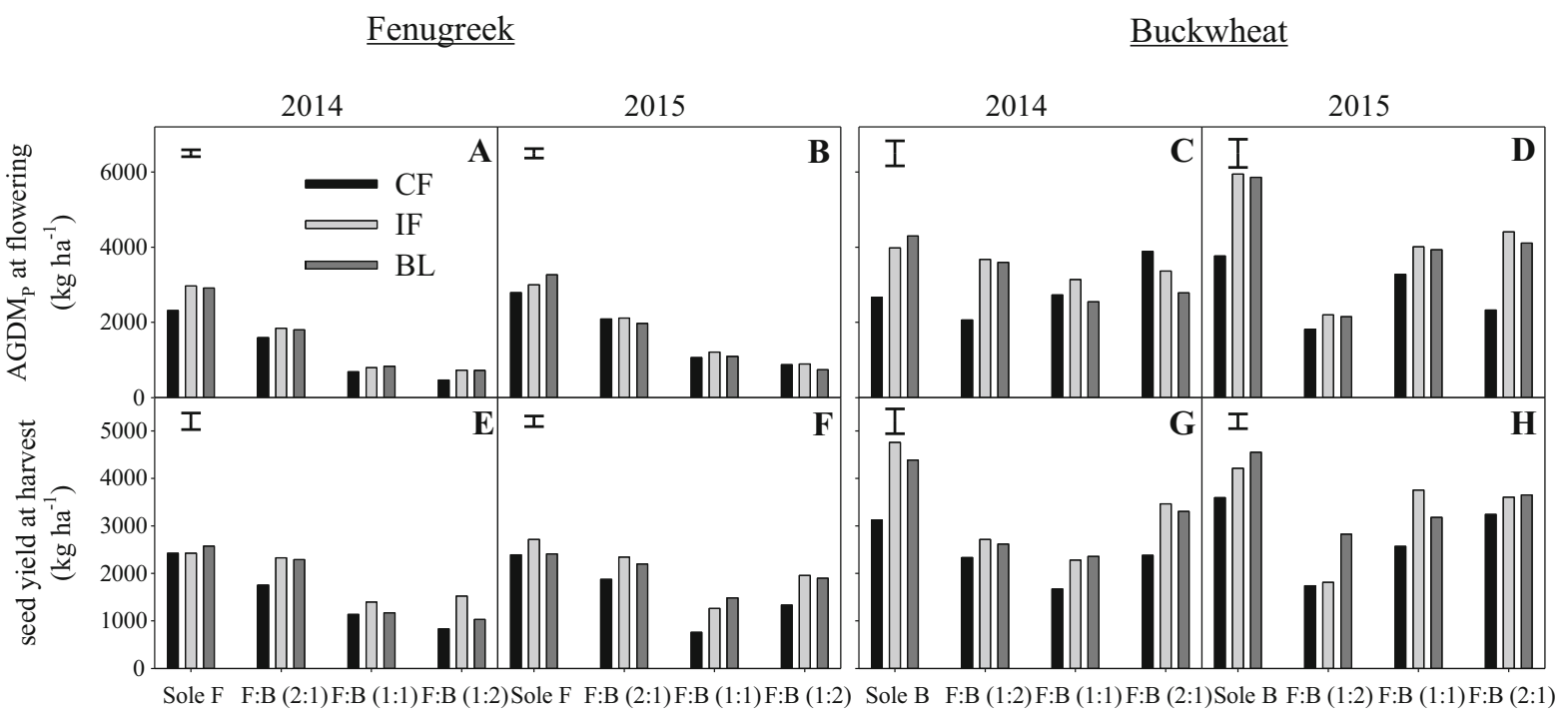

Fig. 1 Above-ground dry matter $\left(\mathrm{AGDM}_{\mathrm{P}}\right)$ at flowering (ad) and seed yield of fenugreek or buckwheat at harvest (e-h) as affected by intercropping ratio and fertilization type in 2014 and 2015. CF, IF, BL are chemical fertilizer, integrated fertilizer, and broiler litter, respectively. F:B (1:2), F:B (1:1) and F:B (2:1)

highest seed yield of buckwheat was found in fenugreek: buckwheat (1:2) of $2825 \mathrm{~kg} \mathrm{ha}^{-1}$ with BL, at fenugreek: buckwheat $(1: 1)$ of $3751 \mathrm{~kg} \mathrm{ha}^{-1}$ with IF at fenugreek: buckwheat $(2: 1)$ of $3652 \mathrm{~kg} \mathrm{ha}^{-1}$ with BL (Fig. 1h).

Total above-ground dry matter (TAGDM)

The TAGDM was significantly affected by intercropping and fertilizer type in both years (Fig. 2a, b). The TAGDM was highest in the intercropped plots on an average by $29 \%$ (2014) and 9\% (2015) as compared to the both sole fenugreek and sole buckwheat, and in both years increased with increasing share of fenugreek in the intercrops [with highest values for fenugreek: buckwheat (2:1)]. Sole buckwheat had a higher TAGDM than sole fenugreek in both years (Fig. 2a, b). The sole fenugreek fertilized with IF and BL treatments had a higher TAGDM on an average by $27 \%$ (2014) and 12\% (2015) than the CF treatments (Fig. 2a, b). The sole buckwheat fertilized with IF and BL treatments had a higher TAGDM on an average by $55 \%$ (2014) and 56\% (2015) than the CF treatments (Fig. 2a, b). In 2014, the TAGDM was higher in the IF and $\mathrm{BL}$ fertilized intercrops, as compared to the $\mathrm{CF}$ is one row of fenugreek + two rows of buckwheat, one row of fenugreek + one row of buckwheat, and two rows of fenugreek + one row of buckwheat, respectively. Error bars are LSD $(p<0.05)$

treatments, except for the fenugreek: buckwheat (2:1) treatment (Fig. 2a). In 2015, a higher TAGDM was observed on an average by $26 \%$ with both IF and BL as compared to CF treatment (Fig. 2b).

Total seed yield

The total seed yield was significantly affected by intercropping and fertilizer type in both years (Fig. 2c, d). Sole buckwheat had a higher seed yield than sole fenugreek in both years. Yet, overall, the total seed yield was higher in the intercropped plots as compared to the sole plots and in 2015 decreased with increasing share of buckwheat (Fig. 2c, d). The highest total seed yield was found in fenugreek: buckwheat $(2: 1)$ for the IF and BL treatments in both years. For sole buckwheat, the IF and BL treatments had a higher seed yield on an average by $46 \%$ (2014) and $22 \%$ (2015) as compared to the CF treatments. In the intercropped plots, a higher total seed yield was also found in the IF and BL treatments, on an average by $31 \%$ (2014) and 30\% (2015) than the CF treatment (Fig. 2c, d). 
Fenugreek + Buckwheat

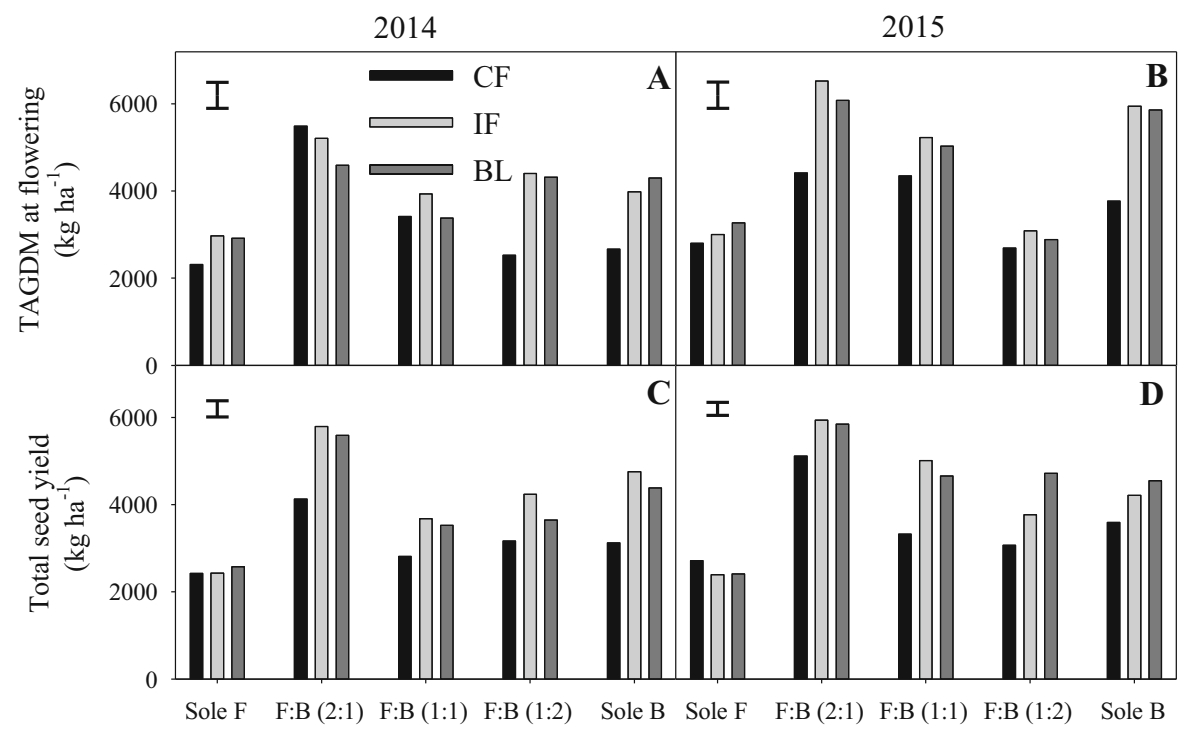

Fig. 2 Total above-ground dry matter (TAGDM) at flowering $(\mathbf{a}, \mathbf{b})$ and total seed yield at harvest of fenugreek and buckwheat (c, d) as affected by intercropping ratio and fertilization type in

$\mathrm{N}$ concentration $\left(\mathrm{N}_{\mathrm{C}}\right)$ and $\mathrm{N}$ uptake $\left(\mathrm{N}_{\mathrm{Up}}\right)$ in $\mathrm{AGDM}_{\mathrm{P}}$

In both years, a significant effect of intercropping and fertilizer type was found for the $\mathrm{N}_{\mathrm{C}}$ in the aboveground dry matter of both fenugreek and buckwheat at the flowering stage (Fig. 3a-d). In the intercropped plots at the flowering stage, the $\mathrm{N}_{\mathrm{C}}$ in the $\mathrm{AGDM}_{\mathrm{P}}$ of fenugreek was higher on an average by $9 \%$ in 2014 and by $7 \%$ in 2015 as compared to the sole fenugreek plots (Fig. 3a, b). The effect was more pronounced in intercrops with IF and BL than with CF fertilizer for fenugreek. For both years, in intercropped plots, the highest $\mathrm{N}_{\mathrm{C}}$ (average of $14 \mathrm{~g} \mathrm{~kg}^{-1}$ ) and lowest (average of $12 \mathrm{~g} \mathrm{~kg}^{-1}$ ) were found in the IF and CF treatments, respectively (Fig. 3a, b).

The $\mathrm{N}_{\mathrm{C}}$ in the $\mathrm{AGDM}_{\mathrm{P}}$ of buckwheat in intercropped plots was higher on an average by $8 \%$ in 2014 as compared to the sole buckwheat plots (Fig. 3c, d). In 2014, the Nc was on an average by $9 \%$ higher in IF and BL treatments compared with CF. In 2015, the IF treatment with fenugreek: buckwheat $(1: 1)$ and the IF and BL treatments with fenugreek: buckwheat $(2: 1)$ had the highest $\mathrm{N}_{\mathrm{C}}$.

In both years, a significant effect of intercropping and fertilizer type was determined for $\mathrm{N}_{U p}$ in the
2014 and 2015. Error bars are LSD $(p<0.05)$. See Fig. 1 for description of treatments

AGDM $_{P}$ of both fenugreek and buckwheat at the flowering stage (Fig. 3e-h). The $\mathrm{N}_{U p}$ in the AGDM $_{P}$ for the sole fenugreek plots was significantly higher on an average by $130 \%$ in 2014 and by $108 \%$ in 2015 than in the intercropped plots (Fig. 3e, f).

In the sole fenugreek plots, the $\mathrm{N}_{\mathrm{Up}}$ was significantly higher with the application of $\mathrm{BL}$, on an average by $27 \%$ (2014) and $23 \%$ (2015) than with CF and IF. In the intercropped plots, $\mathrm{N}_{\mathrm{Up}}$ was highest in the fenugreek: buckwheat $(2: 1)$ and decreased with increasing share of buckwheat in both years (Fig. 3e, f). In 2014, the $\mathrm{N}_{\mathrm{Up}}$ was significantly higher with the application of IF and BL compared with CF. The intercropped treatments fertilized with IF and BL had higher $\mathrm{N}_{\mathrm{Up}}$, on an average by $33 \%$, than with $\mathrm{CF}$. In 2015, there were no significant differences in $\mathrm{N}_{\mathrm{Up}}$ in the intercropped plots (Fig. 3f).

Overall, the $\mathrm{N}_{U p}$ in the $\mathrm{AGDM}_{\mathrm{P}}$ of the sole plots buckwheat was significantly higher than with intercropping, on an average by $10 \%$ in 2014 and by $61 \%$ in 2015 (Fig. 3g, h). In the sole buckwheat plots, $\mathrm{N}_{\mathrm{Up}}$ was significantly higher with the application of both IF and BL on an average by $78 \%$ (2014) and 59\% (2015) than for CF.

In the intercropped plots in $2014, \mathrm{~N}_{\mathrm{Up}}$ was significantly higher in fenugreek: buckwheat (1:2), on an 


\section{Fenugreek}

Buckwheat

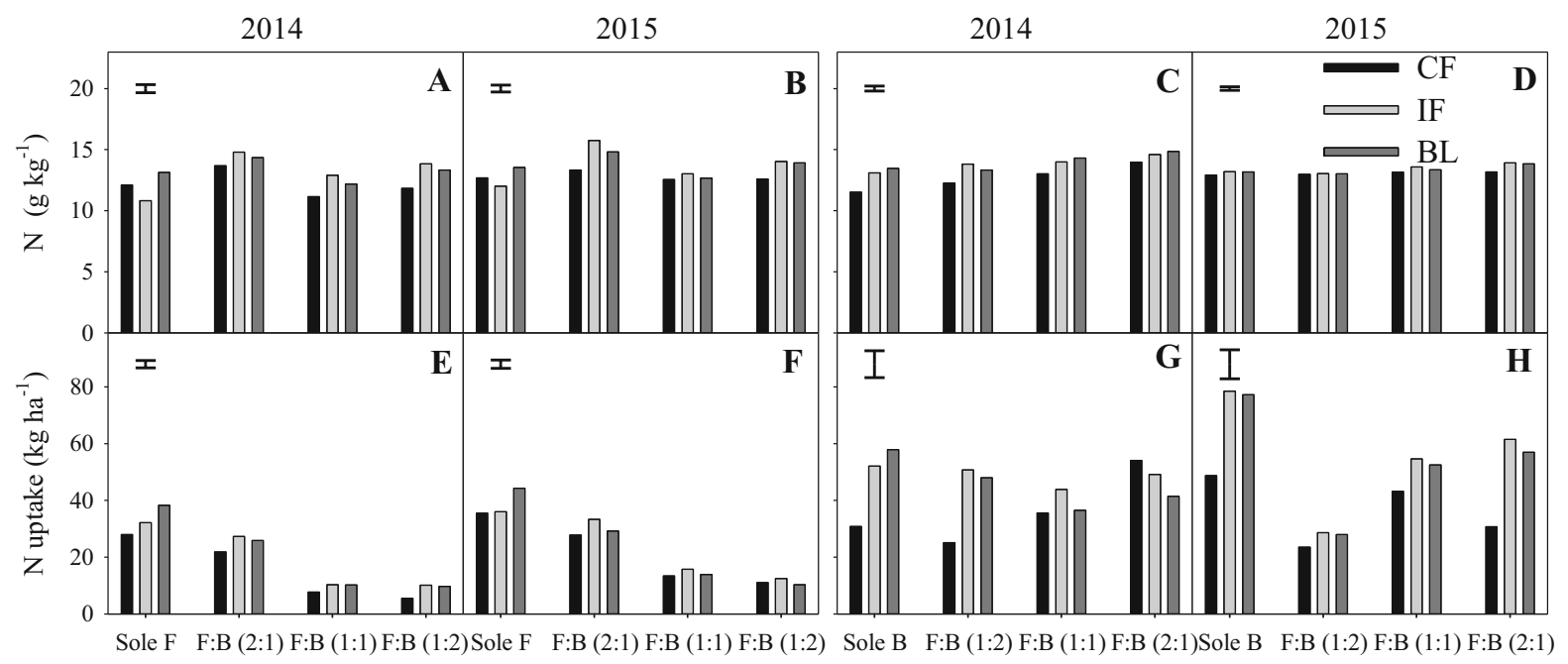

Fig. 3 Nitrogen concentration $\left(\mathrm{N}_{\mathrm{C}}\right)(\mathbf{a}-\mathbf{d})$ and $\mathrm{N}$ uptake $\left(\mathrm{N}_{\mathrm{Up}}\right)$ $(\mathbf{e}-\mathbf{h})$ in the above-ground dry matter of fenugreek or buckwheat at the flowering as affected by intercropping ratio and

average by $96 \%$, with the application of IF and BL compared with CF. In 2014, there were no significant differences in $\mathrm{N}_{\mathrm{Up}}$ in the fenugreek: buckwheat (1:1 and 2:1) plots (Fig. 3g). In 2015, the $\mathrm{N}_{U p}$ was significantly higher with the application of IF and BL compared with CF.

$\mathrm{N}$ concentration $\left(\mathrm{N}_{\mathrm{C}}\right)$ and $\mathrm{N}$ uptake $\left(\mathrm{N}_{\mathrm{Up}}\right)$ in the seeds

For fenugreek, in 2014 only, the $\mathrm{N}_{\mathrm{C}}$ in the seeds was significantly affected by intercropping and fertilizer type (Fig. 4a, b). In the intercropped plots, the $\mathrm{N}_{\mathrm{C}}$ in the seeds was on an average by $9 \%$ higher as compared to the sole plots. In 2014, when IF was applied, the $\mathrm{N}_{\mathrm{C}}$ in the sole plots and fenugreek: buckwheat (1:1) treatment was significantly higher, on an average by 16 and $32 \%$, respectively as compared to the CF treatment (Fig. 4a). In 2015, the fenugreek: buckwheat $(1: 1)$ plots had the highest $\mathrm{N}_{\mathrm{C}}$ with $34.1 \mathrm{~g} \mathrm{~kg}^{-1}$. The lowest $\mathrm{N}_{\mathrm{C}}$ of fenugreek seeds was found in the fenugreek: buckwheat $(2: 1)$ and the sole plots with 27.1 and $28.0 \mathrm{~g} \mathrm{~kg}^{-1}$, respectively (Fig. 4b). The IF treatment had the highest $\mathrm{Nc}$ average of $32.6 \mathrm{~g} \mathrm{~kg}^{-1}$. The CF treatments had the lowest $\mathrm{N}_{\mathrm{C}}$ average of $27.4 \mathrm{~g} \mathrm{~kg}^{-1}$ (Fig. 4b). fertilization type in 2014 and 2015. Error bars are LSD $(p<0.05)$. See Fig. 1 for description of treatments

In 2014, a significant effect of intercropping and fertilizer type was found for $\mathrm{N}_{\mathrm{C}}$ in the buckwheat seeds (Fig. 4c). In the intercropped plots, the $\mathrm{N}_{\mathrm{C}}$ in the seeds was higher on an average by $25 \%$ as compared to the sole buckwheat plots. When CF was applied, the $\mathrm{N}_{\mathrm{C}}$ in the sole buckwheat plots was significantly higher by $13.2 \%$ as compared to the IF and $\mathrm{BL}$ treatments (Fig. 4c). Higher $\mathrm{N}_{\mathrm{C}}$ in the seeds was measured in the IF and BL fertilized treatments of fenugreek: buckwheat $(1: 2)$ on an average by $25 \%$ and also in fenugreek: buckwheat $(1: 1)$ with only IF by $48 \%$ as compared to CF. In 2015, the IF and BL fertilized treatments also had the highest average $\mathrm{Nc}$ in the seeds of $24.5 \mathrm{~g} \mathrm{~kg}^{-1}$. For all planting patterns, the chemical fertilizer had the lowest average seed $\mathrm{N}_{\mathrm{C}}$ of $21.2 \mathrm{~g} \mathrm{~kg}^{-1}$ (Fig. 4d).

In 2014, the $\mathrm{N}_{\mathrm{Up}}$ in the seeds of fenugreek was significantly affected by intercropping ratio and fertilizer type. The sole plots had the highest average $\mathrm{N}_{\mathrm{Up}}$ of $63 \%$ (2014) and 40\% (2015) higher compared with intercropping plots (Fig. 4e, f). The $\mathrm{N}_{U p}$ in seeds of fenugreek decreased with increasing share of buckwheat. The highest $\mathrm{N}_{\mathrm{Up}}$ in seeds of fenugreek in both years were observed in the fenugreek: buckwheat $(2: 1)$ plots. In 2014, the IF and BL treatments had higher $\mathrm{N}_{\mathrm{Up}}$ in seeds of $\mathrm{F}$ by $38 \%$ as compared to the CF treatment (Fig. 4e). In 2015, the $\mathrm{N}_{\mathrm{Up}}$ were 


\section{Fenugreek $\quad \underline{\text { Buckwheat }}$}

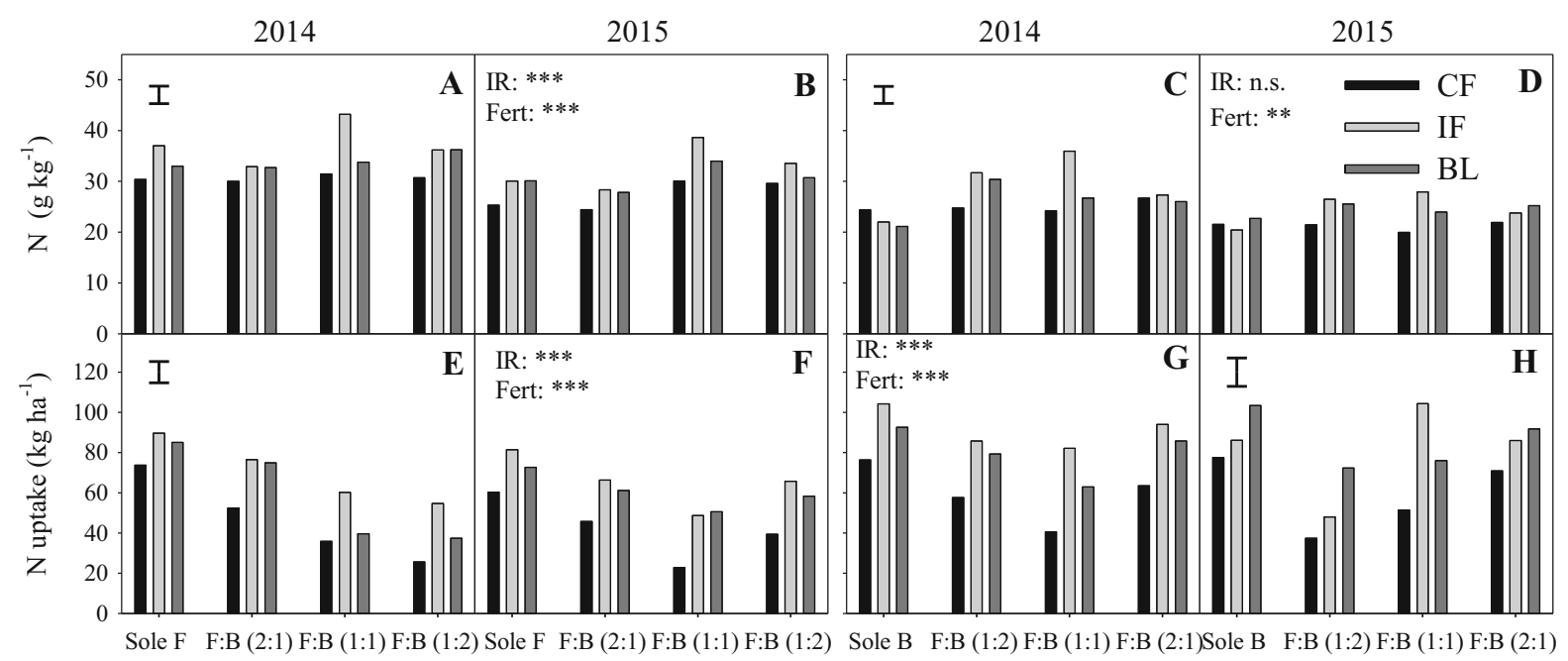

Fig. 4 Nitrogen concentration $\left(\mathrm{N}_{\mathrm{C}}\right)(\mathbf{a}-\mathbf{d})$ and $\mathrm{N}$ uptake $\left(\mathrm{N}_{\mathrm{Up}}\right)$ (e-h) of seeds of fenugreek or buckwheat at harvest as affected by intercropping ratio and fertilization type or main effects in 2014 and 2015. Significant effects are at $p<0.01(* *)$ and

significantly higher with the application of IF by 49.8\% compared with CF (Fig. 4f).

In 2015, the $\mathrm{N}_{\mathrm{Up}}$ in seeds of buckwheat was significantly affected by intercropping and fertilizer type. Overall, in both years, the highest average $\mathrm{N}_{\mathrm{Up}}$ of $81 \mathrm{~kg} \mathrm{ha}^{-1}$ (2014) and $83 \mathrm{~kg} \mathrm{ha}^{-1}$ were obtained with a higher share of fenugreek (fenugreek: buckwheat (2:1)) in the intercropped treatments (Fig. $4 \mathrm{~g}, \mathrm{~h}$ ). In 2014 , the highest $\mathrm{N}_{\mathrm{Up}}$ of $91 \mathrm{~kg} \mathrm{ha}^{-1}$ was recorded in sole buckwheat plots. The lowest $\mathrm{N}_{\mathrm{Up}}$ in the seeds of buckwheat was observed for fenugreek: buckwheat (1:1) with $61.6 \mathrm{~kg} \mathrm{ha}^{-1}$ (Fig. $4 \mathrm{~g}$ ). In 2014, the sole plots fertilized with both IF and BL had higher average $\mathrm{N}_{\mathrm{Up}}$ of $28.9 \%$ as compared to the $\mathrm{CF}$ treatments (Fig. 4g). Overall, in the intercropped plots, the $\mathrm{N}_{\mathrm{Up}}$ was significantly higher with the application of both IF and $\mathrm{BL}$ on an average by $51 \%$ as compared to the $\mathrm{CF}$ treatment (Fig. 4g).

In 2015 in the sole buckwheat plots, the $\mathrm{N}_{\mathrm{Up}}$ was significantly higher by an average of $25 \%$ compared to the intercropped plots (Fig. 4h). In 2015, the lowest $\mathrm{N}_{\mathrm{Up}}$ in the seeds of buckwheat was observed for fenugreek: buckwheat (1:2) with $52.5 \mathrm{~kg} \mathrm{ha}^{-1}$ (Fig. 4h). The sole buckwheat plots fertilized with BL had higher $\mathrm{N}_{\mathrm{Up}}$ by $26 \%$ as compared to the both IF and CF treatments. Overall, in intercropped plots, the highest $\mathrm{N}_{\mathrm{Up}}$ accumulated with application of both IF $p<0.001(* * *)$. Error bars are LSD $(p<0.05) . I R=$ intercropping ratio, Fert $=$ fertilization type. See Fig. 1 for description of treatments

and BL on an average by $49.8 \%$ as compared to the $\mathrm{CF}$ treatments (Fig. 4h).

$\mathrm{P}$ concentration $\left(\mathrm{P}_{\mathrm{C}}\right)$ and $\mathrm{P}$ uptake $\left(\mathrm{P}_{\mathrm{Up}}\right)$ in $\mathrm{AGDM}_{\mathrm{P}}$

Intercropping and fertilizer type significantly affected the $\mathrm{P}_{\mathrm{C}}$ in the $\mathrm{AGDM}_{\mathbf{P}}$ during the flowering stage of fenugreek and buckwheat in both years (Fig. 5a-d).

In both years for fenugreek, in the intercropped plots, the $\mathrm{P}_{\mathrm{C}}$ was on an average by $6 \%$ higher as compared to the sole fenugreek plots (Fig. 5a, b). Similar to the $\mathrm{N}_{\mathrm{C}}$ results, the effect was more pronounced with IF and BL than with $\mathrm{CF}$ fertilizer. The highest Pc values were in fenugreek: buckwheat (2:1) plots fertilized with BL with $4.0 \mathrm{~g} \mathrm{~kg}^{-1}$ in both year (Fig. 5a, b).

For buckwheat, in the intercropped plots at the flowering stage, the $\mathrm{P}_{\mathrm{C}}$ significantly exceeded on an average by $12 \%$ in 2014 the sole buckwheat plots (Fig. 5c, d). Similar to the $\mathrm{N}_{\mathrm{C}}$ results, the effect was more pronounced with IF and $\mathrm{BL}$ than with $\mathrm{CF}$ fertilizer in both years. The $\mathrm{P}_{C}$ in the $\mathrm{AGDM}_{\mathrm{P}}$ in sole buckwheat plots was higher on an average by $6.8 \mathrm{~g} \mathrm{~kg}^{-1}$ (2014) and $4.6 \mathrm{~g} \mathrm{~kg}^{-1}$ (2015) in the both IF and $\mathrm{BL}$ treatments than with $\mathrm{CF}$ treatment. In the intercropped plots, the highest $\mathrm{P}_{\mathrm{C}}$ was found in the 


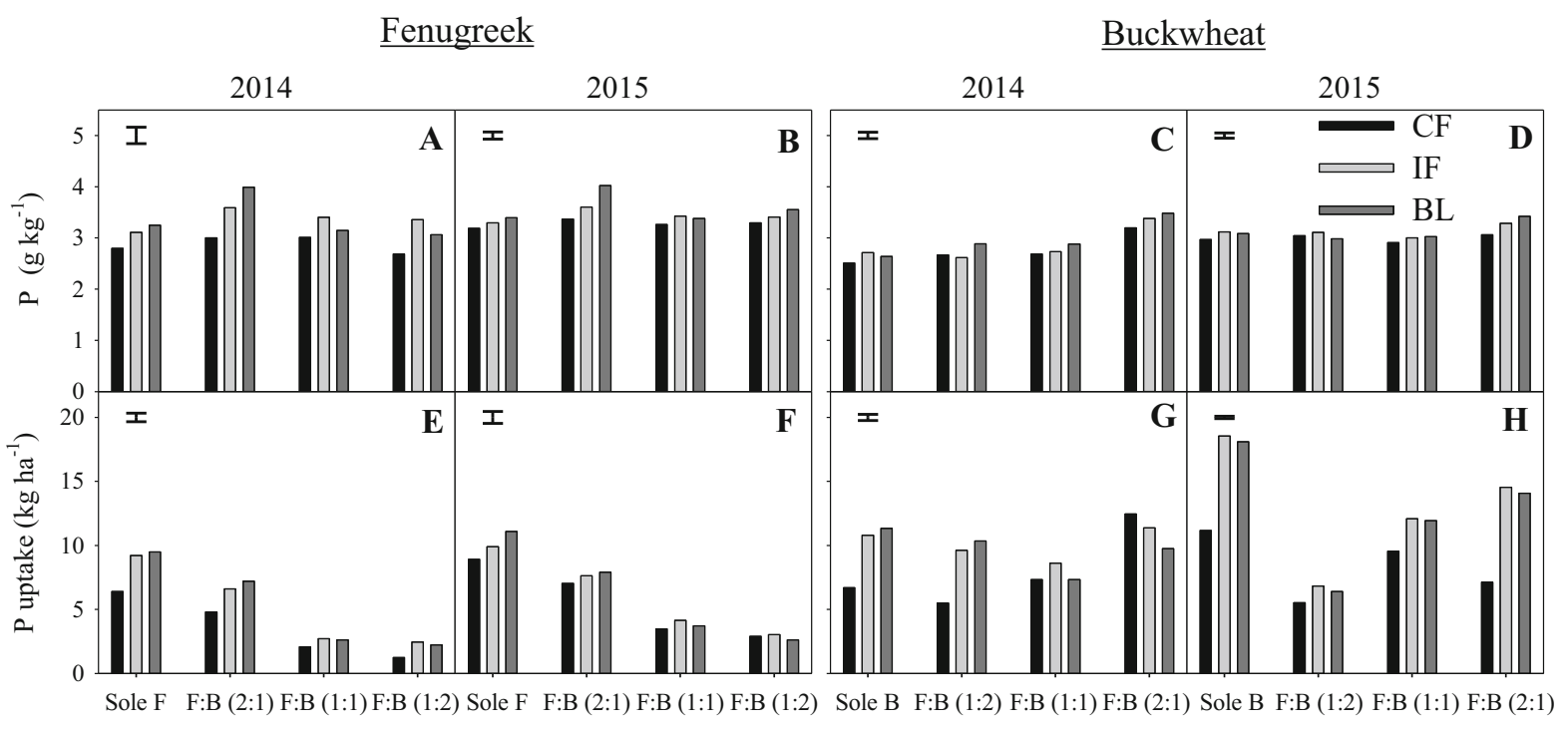

Fig. 5 Phosphorus concentrations $\left(\mathrm{P}_{\mathrm{C}}\right)(\mathbf{a}-\mathbf{d})$ and $\mathrm{P}$ uptake $\left(\mathrm{P}_{\mathrm{Up}}\right)(\mathbf{e}-\mathbf{h})$ in the above-ground dry matter of fenugreek or buckwheat at flowering as affected by intercropping ratio and

fenugreek: buckwheat $(2: 1)$ with $\mathrm{BL}$ treatment, at $3.5 \mathrm{~g} \mathrm{~kg}^{-1}$ in 2014 and $3.4 \mathrm{~g} \mathrm{~kg}^{-1}$ in 2015 .

The $\mathrm{P}_{\mathrm{Up}}$ for both fenugreek and buckwheat was also significantly affected by intercropping and fertilizer type (Fig. 5e-h). For fenugreek in both years, $\mathrm{P}_{\mathrm{Up}}$ was highest in the sole plots and decreased with increasing share of buckwheat (Fig. 5e, f). In both years a higher $\mathrm{P}_{\mathrm{Up}}$ was found in the IF and BL treatments on an average by $46 \%$ (2014) and $12 \%$ as compared to $\mathrm{CF}$ (Fig. 5e, f). In the intercropped plots, the highest $\mathrm{P}_{\mathrm{Up}}$ was measured in the fenugreek: buckwheat $(2: 1)$ with BL treatment, at $7.2 \mathrm{~kg} \mathrm{ha}^{-1}$ in 2014 and $7.9 \mathrm{~kg} \mathrm{ha}^{-1}$ in 2015 (Fig. 5e, f).

The results of buckwheat followed the same pattern as for $\mathrm{N}_{\mathrm{Up}}$. In 2015, $\mathrm{P}_{\mathrm{Up}}$ of buckwheat was highest in the sole plots and increased with increasing share of fenugreek in intercropped plots in both years (Fig. $5 \mathrm{~g}$, h). The sole plots fertilized with IF and BL showed a higher $\mathrm{P}_{\mathrm{Up}}$ in the $\mathrm{AGDM}_{\mathbf{P}}$ on an average by $65 \%$ (2014) and 64\% (2015) than for CF treatment. In 2014 a higher $\mathrm{P}_{\mathrm{Up}}$ was found in the $\mathrm{BL}$ fertilized fenugreek: buckwheat (1:2) plots by $88 \%$ as compared to CF. In 2014, there were no significant differences in $\mathrm{P}_{\mathrm{Up}}$ in the fenugreek: buckwheat (1:1 and 2:1) intercropped plots (Fig. 5g). In 2015, in the intercropped plots, the highest $\mathrm{P}_{\mathrm{Up}}$ was measured on an average by $48 \%$ with both IF and BL treatments as compared to CF (Fig. $5 \mathrm{~g}$, h). fertilization type in 2014 and 2015. Error bars are LSD $(p<0.05)$. See Fig. 1 for description of treatments

$\mathrm{P}$ concentration $\left(\mathrm{P}_{\mathrm{C}}\right)$ and $\mathrm{P}$ uptake $\left(\mathrm{P}_{\mathrm{Up}}\right)$ in the seeds

For fenugreek, in 2014 only, the $\mathrm{P}_{\mathrm{C}}$ in the seeds was significantly affected by intercropping and fertilizer type (Fig. 6a, b). In 2014, fenugreek seeds showed higher $\mathrm{P}_{\mathrm{C}}$ (on an average by $10 \%$ ) in intercropped plots than the sole cropped plots (Fig. 6a). In 2014, when IF was applied, the seed $\mathrm{P}_{\mathrm{C}}$ in the sole plots was significantly higher, by $12 \%$ as compared to the $\mathrm{CF}$, while in the intercropped plots, the seed $\mathrm{P}_{\mathrm{C}}$ was significantly higher by $20 \%$ average in BL treatments than with CF and IF treatments. In 2015, the fenugreek: buckwheat (2:1) and fenugreek: buckwheat (1:1) treatments had the highest $\mathrm{P}_{\mathrm{C}}$ in seeds with 5.0 and $4.6 \mathrm{~g} \mathrm{~kg}^{-1}$, respectively (Fig. 6b). Also, a higher $\mathrm{P}_{\mathrm{C}}$ in seeds was found in the organically fertilized treatments (IF, BL) on an average by $24 \%$ than in the CF treatments (Fig. 6b).

In 2014, buckwheat seeds showed a higher $P_{C}$ in the fenugreek: buckwheat (1:1) and fenugreek: buckwheat (1:2) intercropped treatments of 4.2 and $4.1 \mathrm{~g} \mathrm{~kg}^{-1}$, respectively (Fig. 6c). In 2015, the fenugreek: buckwheat (1:1) and fenugreek: buckwheat (1:2) treatments had higher $P_{C}$ in seed with 4.7 and $4.5 \mathrm{~g} \mathrm{~kg}^{-1}$ respectively (Fig. 6d). The lowest $\mathrm{P}_{\mathrm{C}}$ in seeds with $3 \mathrm{~g} \mathrm{~kg}^{-1}$ (2014) and $3.1 \mathrm{~g} \mathrm{~kg}^{-1}$ (2015) were found in the sole buckwheat plots and fenugreek: buckwheat 


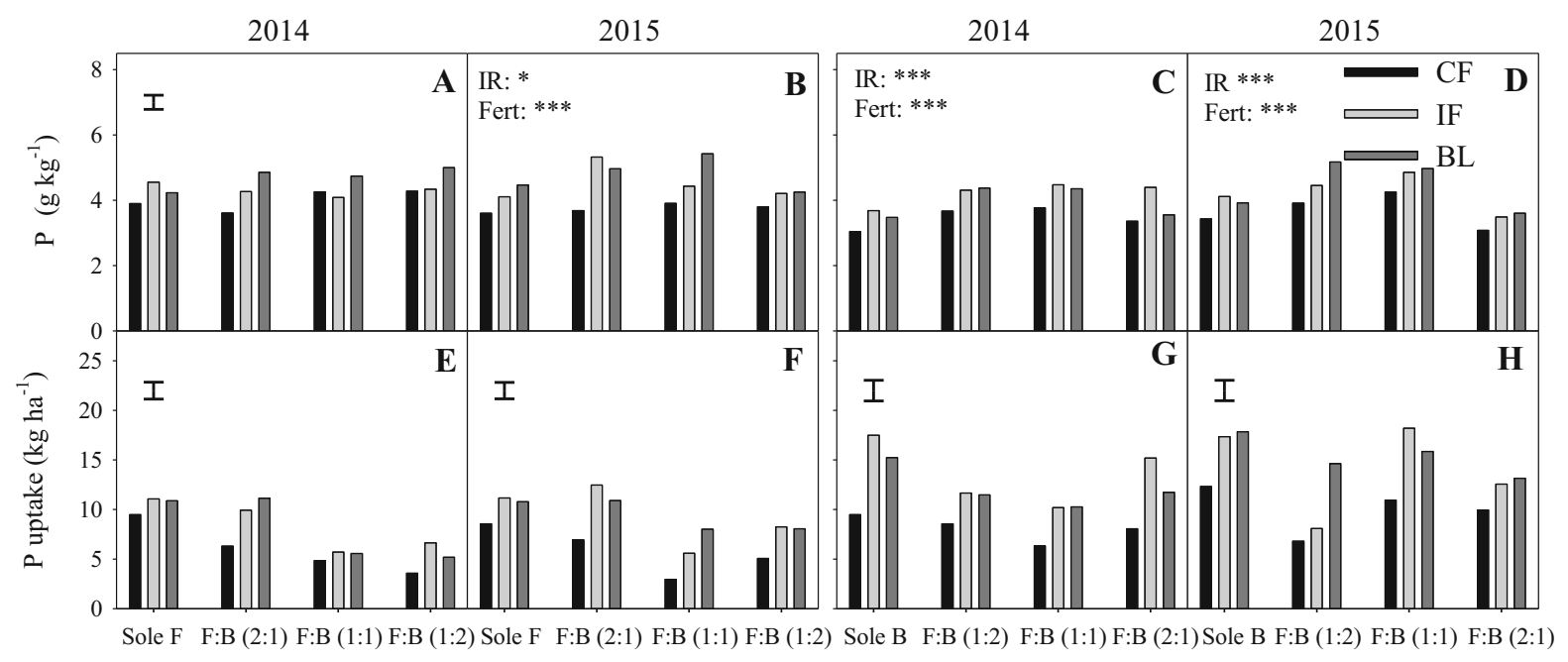

Fig. 6 Phosphorus concentrations $\left(\mathrm{P}_{\mathrm{C}}\right)(\mathbf{a}-\mathbf{d})$ and $\mathrm{P}$ uptake $\left(\mathrm{P}_{\mathrm{Up}}\right)(\mathbf{e}-\mathbf{h})$ of seeds of fenugreek or buckwheat at harvest as affected by intercropping ratio and fertilization type or main effects in 2014 and 2015. Significant effects are at $p<0.01(* *)$

(2:1) plots, repectively (Fig. 6c, d). In 2014, when IF was applied, the $\mathrm{P}_{C}$ was significantly higher by $22 \%$ as compared to $\mathrm{CF}$. A significantly higher $\mathrm{P}_{\mathrm{C}}$ in seed was found in the IF $\left(4.2 \mathrm{~g} \mathrm{~kg}^{-1}\right)$ and $\mathrm{CF}\left(3.7 \mathrm{~g} \mathrm{~kg}^{-1}\right)$ treatments (Fig. 6c, d).

In both years, the $\mathrm{P}_{\mathrm{Up}}$ in the seeds of fenugreek and buckwheat was significantly affected by intercropping and fertilizer type (Fig. 6e-h). Fenugreek seeds showed a tendency towards higher $\mathrm{P}_{\mathrm{Up}}$ in sole plots than in the intercropped plots and the $\mathrm{P}_{\mathrm{Up}}$ decreased with increasing share of buckwheat in intercropping (Fig. 6e, f). The highest $\mathrm{P}_{\mathrm{Up}}$ in seeds of fenugreek was found in the fertilized fenugreek: buckwheat $(2: 1)$ plots with $11.1 \mathrm{~kg} \mathrm{ha}^{-1}$ in the BL treatment (2014) and $12.5 \mathrm{~kg} \mathrm{ha}^{-1}$ in the IF treatment (2015). The IF and $\mathrm{BL}$ treatments had more $\mathrm{P}_{\mathrm{Up}}$ in the seeds on an average by $36 \%$ (2014) and 60\% (2015), respectively, as compared to $\mathrm{CF}$ treatments (Fig. 6e, f).

Overall, the $\mathrm{P}_{\mathrm{Up}}$ in the buckwheat seeds increased with a higher share of fenugreek in intercropping plots (Fig. 6g, h). In the sole buckwheat plots, the $\mathrm{N}_{\mathrm{Up}}$ in the seed was significantly higher, on an average by $35 \%$ in 2014 and by $29 \%$ in 2015, respectively (Fig. 6g, h). The sole buckwheat plots fertilized with IF and BL showed a higher $\mathrm{P}_{\mathrm{Up}}$ in the seed on an average by $72 \%$ (2014) and 42\% (2015) than for CF treatment (Fig. 6g, h). In the intercropped plots IF and BL treatments had and $p<0.001\left(^{* * *}\right)$. Error bars are LSD $(p<0.05) . I R=$ intercropping ratio, Fert $=$ fertilization type. See Fig. 1 for description of treatments

the highest $\mathrm{P}_{\mathrm{Up}}$ on an average by 53\% (2014) and by $66 \%$ (2015).

Total above-ground dry matter nitrogen land equivalent ratio (TAGDM N-LER)

A significant effect of intercropping and fertilizer type was found for the TAGDM N-LER in both years (Fig. 7a, b). In both years, the TAGDM N-LER increased with increasing share of fenugreek. The TAGDM N-LER ranged from 0.9 to 2.6 (in 2014) and from 0.6 to 1.7 (in 2015). In 2014, the highest TAGDM N-LER was found in fenugreek: buckwheat (2:1) fertilized with CF with a N-LER of 2.6. In 2015, it was in fenugreek: buckwheat $(2: 1)$ fertilized with IF at 1.7 (Fig. 7a, b).

Total above-ground dry matter phosphorus land equivalent ratio (TAGDM P-LER)

A significant effect of intercropping and fertilizer type was found for the TAGDM P-LER in both years (Fig. 7c, d). Similar to TAGDM N-LER, in both years the TAGDM P-LER increased with increasing share of fenugreek. The TAGDM P-LER ranged from 0.9 to 2.7 (in 2014) and from 0.6 to 1.6 (in 2015). In 2014, the highest TAGDM P-LER of 2.7 was found in fenugreek: buckwheat (2:1) fertilized with CF and in 2015, 


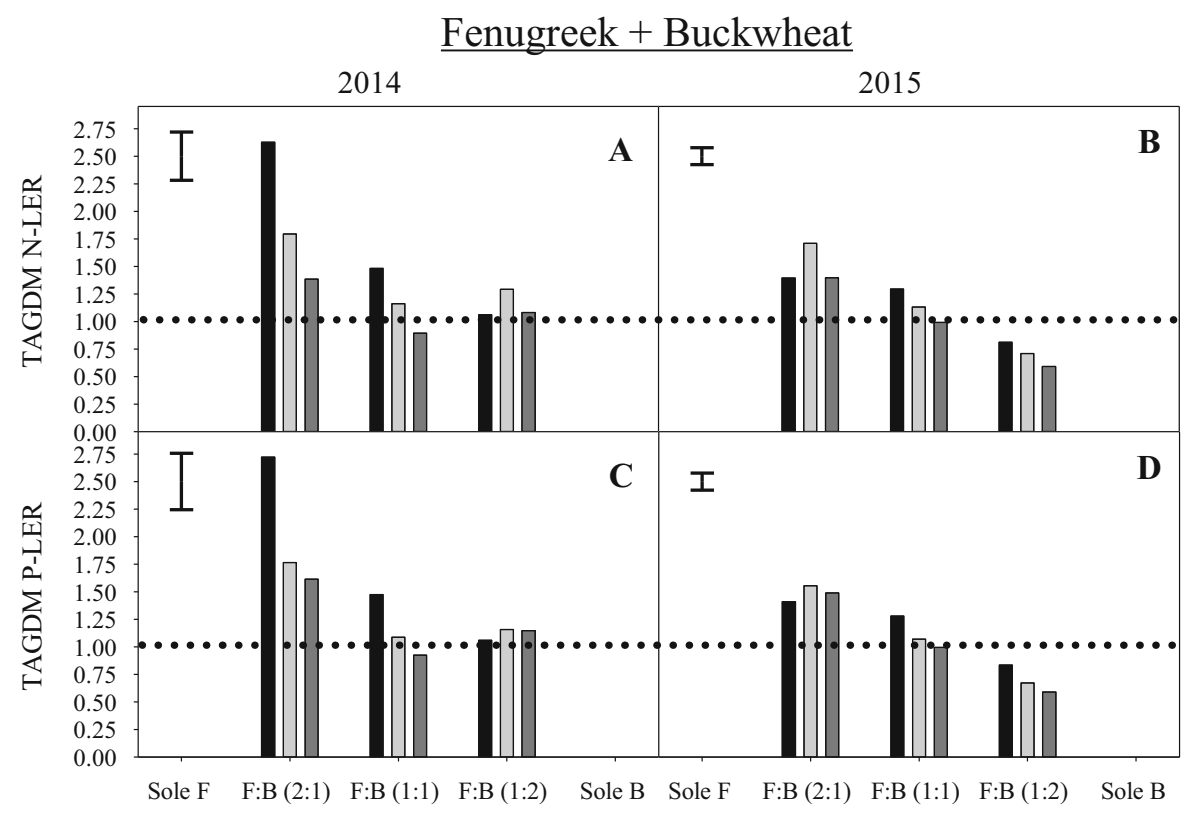

Fig. 7 Total N-land equivalent ratio for total AGDM (TAGDM $\mathrm{N}$-LER) (a, b) and total P-land equivalent ratio for total AGDM (TAGDM P-LER) (c, d) of fenugreek and buckwheat at flowering stage in as affected by intercropping ratio and

it was 1.6 in the fenugreek: buckwheat $(2: 1)$ fertilized with IF (Fig. 7c, d).

Total $\mathrm{N}$ uptake in seeds $\left(\mathrm{TN}_{\mathrm{Up}}\right)$

The $\mathrm{TN}_{\mathrm{Up}}$ in seeds was significantly affected by intercropping and fertilizer type in both years (Fig. 8a, b). In the intercropped plots, $\mathrm{TN}_{\mathrm{Up}}$ in seeds was on an average by $41 \%$ in (2014) and 51\% (2015) higher as compared to the sole plots and decreased with increasing share of buckwheat in 2015. The $\mathrm{TN}_{\mathrm{Up}}$ was higher with IF and BL than with CF fertilizer. Sole buckwheat had a higher $\mathrm{TN}_{\mathrm{UP}}$ in seeds than sole fenugreek in both years (Fig. 8a, b). The sole fenugreek fertilized with both IF and BL treatments had a higher $\mathrm{TN}_{\mathrm{Up}}$ in seeds on an average by $18 \%$ (2014) and 27\% (2015) than for CF treatments (Fig. 8a, b). The sole buckwheat fertilized with both IF and BL treatments had a higher $\mathrm{TN}_{\mathrm{Up}}$ in seeds on an average by $28 \%$ (2014) and $22 \%$ (2015) than for CF treatments (Fig. 8a, b). In the intercropped plots, IF and BL treatments had the highest $\mathrm{TN}_{\mathrm{Up}}$ in seeds on an average by $51 \%$ (2014) and by $54.9 \%$ (2015) as compared to the CF treatment (Fig. 8a, b). fertilization type in 2014 and 2015. Error bars are LSD $(p<0.05)$. The dotted line in $\mathbf{a}-\mathbf{d}$ are at LER $=1$; values $>1$ indicate a TAGDM advantage. See Fig. 1 for description of treatments

\section{Total N-LER}

In both years, the total N-LER was significantly affected by the interaction of intercropping and fertilizer type (Fig. 8c, d). In all treatments, the total $\mathrm{N}$-LER was above unity and on average increased with increasing share of fenugreek in both years. In 2014 the highest N-LER was in fenugreek: buckwheat $(2: 1)$ fertilized with BL and in 2015 in fenugreek: buckwheat (1:1) fertilized with IF (both times with 1.8). The IF and BL fertilized intercrops had higher total N-LER on an average by $27 \%$ (2014) and 26\% (2015) than for the CF treatment (Fig. 8c, d).

Applied $\mathrm{N}$ use efficiency (ANUE) and applied $\mathrm{N}$ recovery efficiency (ANRE) in seeds

In both years, a significant interaction effect of intercropping and fertilizer type was found on ANUE (Fig. 8e, f). A higher ANUE on an average by $112 \%$ (2014) and 113\% (2015) was obtained in sole buckwheat as compared to sole fenugreek. Also, the intercrops had a higher ANUE than the sole fenugreek. The highest ANUE was found in fenugreek: buckwheat $(2: 1)$ treatment on an average by $49.0 \mathrm{~kg} \mathrm{~kg}^{-1}$ 
Fenugreek + Buckwheat

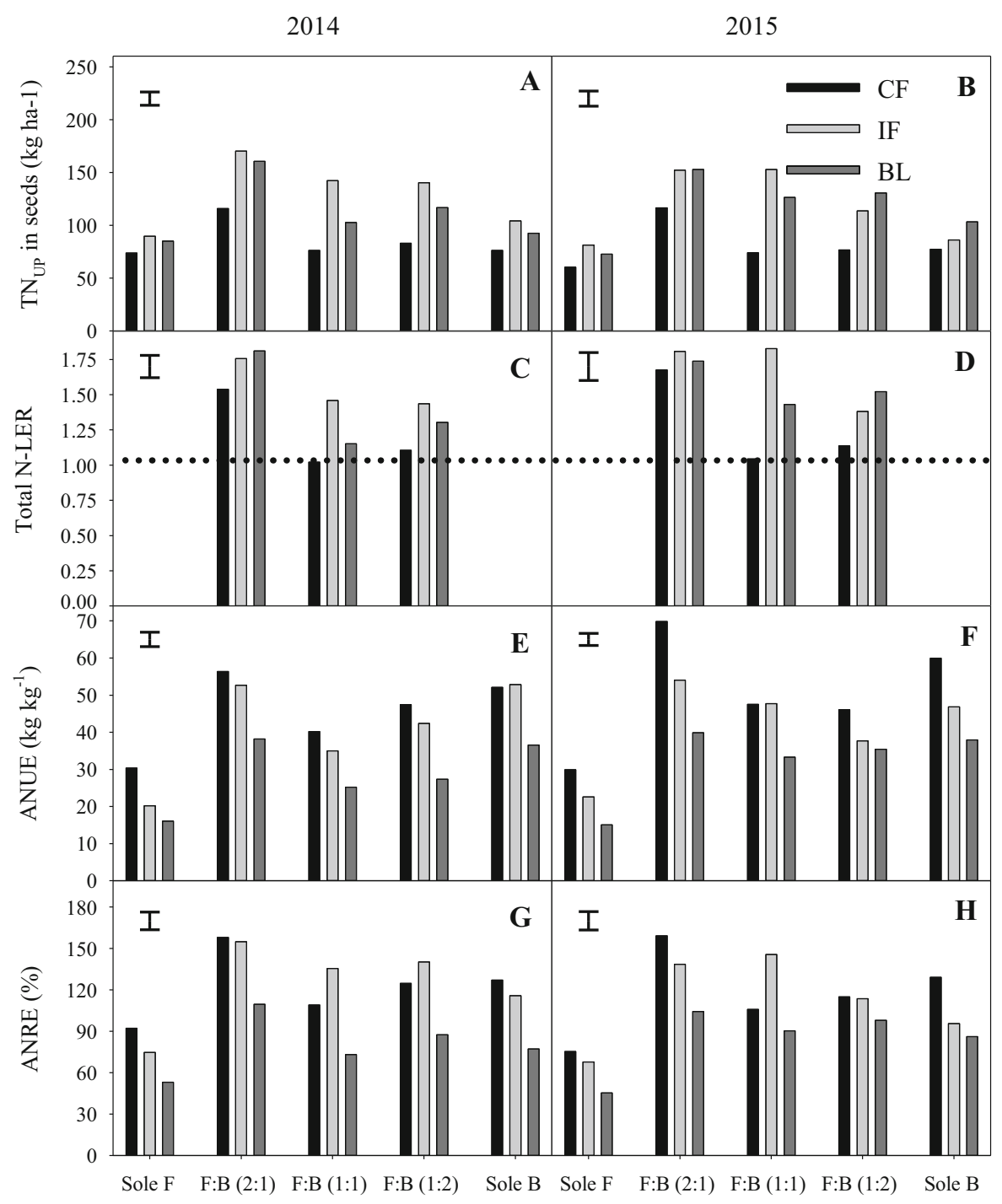

Fig. 8 Total $\mathrm{N}$ uptake $\left(\mathrm{TN}_{\mathrm{Up}}\right)$ in seeds $(\mathbf{a}, \mathbf{b})$, total $\mathrm{N}$-land equivalent ratio (total $\mathrm{N}$-LER) for seeds $(\mathbf{c}, \mathbf{d})$, applied $\mathrm{N}$ use efficiency (ANUE) $(\mathbf{e}, \mathbf{f})$ and applied $\mathrm{N}$ recovery efficiency (ANRE) (g, h) of fenugreek and buckwheat at harvest as

(2014) and $54.6 \mathrm{~kg} \mathrm{~kg}^{-1}$ (2015). Overall, in the intercrops, the higher ANUE was obtained with CF (on an average by $48.0 \mathrm{~kg} \mathrm{~kg}^{-1}$ in 2014 and $54.5 \mathrm{~kg} \mathrm{~kg}^{-1}$ in 2015) followed by IF $\left(43.3 \mathrm{~kg} \mathrm{~kg}^{-1}\right.$ in 2014 and $46.5 \mathrm{~kg} \mathrm{~kg}^{-1}$ in 2015) (Fig. 8e, f).

In both years, the ANRE was significantly affected by the interaction of intercropping and fertilizer type (Fig. 8g, h). A higher ANRE was obtained in sole buckwheat as compared to sole fenugreek. In the intercrops, ANRE was significantly higher on an affected by intercropping ratio and fertilization type in 2014 and 2015. Error bars are LSD $(p<0.05)$. The dotted line in $\mathbf{c}$ and $\mathbf{d}$ is at $\mathrm{LER}=1$; values $>1$ indicate a yield advantage. See Fig. 1 for description of treatments

average by $34 \%$ (2014) and $43 \%$ (2015) as compared to both sole crops and increased with increasing share of fenugreek in 2015 (Fig. 8g, h).

The highest ANRE was found in fenugreek: buckwheat (2:1) on an average by $140 \%$ (2014) and $134 \%$ (2015). In 2014, in the intercrops, the higher ANRE was obtained with IF treatment (on an average by $143 \%$ ) followed by the CF treatment (on an average by $130 \%$ ). In 2015 , in the fertilized intercrops, the 
effect of CF treatment of ANUE was more pronounced (Fig. 8g, h).

Total $\mathrm{P}$ uptake in seeds $\left(\mathrm{TP}_{\mathrm{Up}}\right)$

The $\mathrm{TP}_{\mathrm{UP}}$ in seeds was significantly affected by intercropping and fertilizer type in both years (Fig. 9a, b). In the intercrops, $\mathrm{TP}_{\mathrm{UP}}$ in seeds increased on an average by $37 \%$ (2014) and by $52 \%$ (2015) as compared to both sole crops and increased with increasing share of fenugreek in 2015. The effect was more pronounced with $\mathrm{IF}$ and $\mathrm{BL}$ than with $\mathrm{CF}$ fertilization.

Sole buckwheat had a higher $\mathrm{TP}_{\mathrm{UP}}$ in seeds than sole fenugreek in both years (Fig. 9a, b). The sole fenugreek treatments fertilized with both IF and BL had a higher $\mathrm{TP}_{\mathrm{UP}}$ in seeds on an average by $15 \%$ (2014) and 28\% (2015) than for CF treatments (Fig. 9a, b). When IF and BL were applied, the $\mathrm{TP}_{\mathrm{UP}}$ in seeds of sole buckwheat plots was significantly higher by $72 \%$ (2014) and $42 \%$ (2015) than with CF. A higher $\mathrm{TP}_{\mathrm{Up}}$ in seeds was found in the IF and $\mathrm{BL}$ fertilized treatments, on an average by $52 \%$ (2014) and $59 \%$, as compared to $\mathrm{CF}$.
In Tables 1 and 2 for fenugreek and buckwheat, at the flowering stage and for seed yield, the macronutrient uptakes $\left(\mathrm{N}_{\mathrm{Up}}\right.$ and $\left.\mathrm{P}_{\mathrm{Up}}\right)$ were positively correlated with AGDM and seed yield in 2014 and 2015.

\section{Total P-LER}

In both years, the total P-LER was significantly affected by of intercropping and fertilizer type (Fig. 9c, d). In both years, total P-LER was above unity in all treatments and increased with increasing share of fenugreek. The highest total P-LER were found for fenugreek: buckwheat (2:1) fertilized with BL and IF (with 1.8).

In 2014, when IF and BL were applied, the total P-LER in the fenugreek: buckwheat (2:1) plots was significantly higher by $15 \%$ than with CF (Fig. 9c). In 2015, a higher total P-LER was found in the IF and BL fertilized intercrops on an average by $26 \%$, as compared to CF (Fig. 9d).

\section{$\underline{\text { Fenugreek }+ \text { Buckwheat }}$}

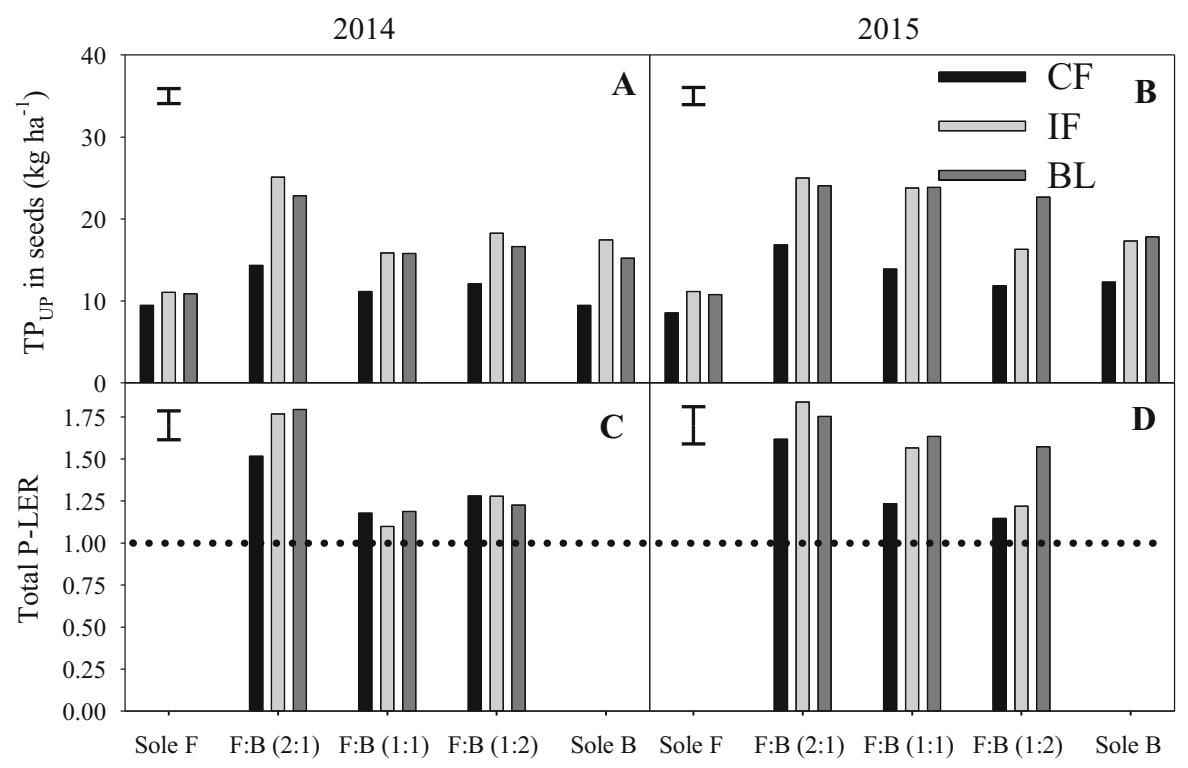

Fig. 9 Total $\mathrm{P}$ uptake $\left(\mathrm{TP}_{\mathrm{Up}}\right)$ in seeds $(\mathbf{a}, \mathbf{b})$, total P-land equivalent ratio (P-LER) for seeds (c, d) of fenugreek and buckwheat at harvest as affected by intercropping ratio and fertilization type in 2014 and 2015. Error bars are LSD $(p<0.05)$. The dotted line in $\mathbf{c}$ and $\mathbf{d}$ is at LER $=1$; values $>1$ indicate a yield advantage. See Fig. 1 for description of treatments 


\section{Discussion}

Intercropping resulted in higher AGDM (both $\mathrm{AGDM}_{\mathrm{P}}$ and TAGDM) at the flowering stage and higher total seed yields as compared to pure stands. The intercropping treatment with 2:1 fenugreek: buckwheat had particularly better results. The higher yields in intercrops were mainly governed by a higher share of fenugreek. One reason for the higher biomass with increasing share of fenugreek may be that there is more $\mathrm{N}$ available through $\mathrm{N}$-fixation as fenugreek is a legume. Salehi et al. (2016) reported that the highest seed yield of fenugreek and buckwheat was found with fenugreek: buckwheat (2:1) intercropped with organic manure. Similar to our results, Osman and Nersoyan (1986) found that the highest dry matter yields in cereal-common vetch intercrops for forage production were related to a high share of the legume partner.

A higher AGDM at the flowering stage and higher seed yields with both IF and BL compared with mineral fertilizer could be the result of several factors, such as the effect of broiler litter supplying more nutrients over the growing season for plant growth and seed filling. For example, Ghosh et al. (2009) reported that integrated application of chemical with organic fertilizers (farm yard and poultry manure) produced higher seed yield of soybean intercropped with sorghum, as compared to mineral fertilizer. Our results corroborate with a study by Rostaei et al. (2014) who reported that application of broiler litter on intercropped fenugreek-black cumin (Nigella sativa L.) resulted in higher seed yield in both crops than in sole crops supplied with chemical fertilizers, especially for higher shares of fenugreek. As well, broiler litter can improve the soil chemical, physical and biological properties as compared to the chemical fertilizers (Tejada et al. (2011). Fereidooni et al. (2013) also reported the application of broiler litter increased soil organic matter and microbial activity and had a higher potential for enzyme activity leading to higher maize yields. Finally, Fallah et al. (2013) explained that the small decline in soil $\mathrm{pH}$ could be attributed to the nitrification of $\mathrm{NH}_{4}$ and various organic acids produced during the decomposition of the labile fraction of the manure that could be helpful to improve yield.

The $\mathrm{N}$ and $\mathrm{P}$ concentration in the $\mathrm{AGDM}_{\mathrm{P}}$ and seeds of both fenugreek and buckwheat were higher in intercrops than for sole crops. The $\mathrm{N}$ and $\mathrm{P}$ concentrations in the $\mathrm{AGDM}_{\mathrm{P}}$ were generally higher in both fenugreek and buckwheat intercropped with a high share of fenugreek [fenugreek: buckwheat (2:1)]; whereas, in the seeds the $\mathrm{N}$ and $\mathrm{P}$ concentrations were higher in the fenugreek: buckwheat (1:1). Similarly, Bedoussac and Justes (2010) reported that intercropped wheat with pea resulted in a $50 \%$ higher $\mathrm{N}$ content in wheat seeds as compared to the sole wheat. Advantages of intercropping cereals with legumes are attributed to a more efficient utilization of resources such as nitrogen (Musa et al. 2010). Neugschwandtner and Kaul (2015) found a higher grain $\mathrm{N}$ content of oat in mixtures with an even share of oat:pea (50:50), explaining this by the higher availability of soil mineral $\mathrm{N}$ per unit area for individual oat plants due to reduced intraspecific competition at lower oat density and less interspecific competition with an $\mathrm{N}$-fixing legume companion crop.

The results suggest that broiler litter and integrated fertilizer are recommendable for increasing macronutrient $(\mathrm{N}, \mathrm{P})$ concentrations in both AGDM and seeds of fenugreek-buckwheat intercrops. According to Fallah et al. (2013), adding poultry manure to chemical fertilizers provides an optimum balance between $\mathrm{N}$ and $\mathrm{P}$ in the calcareous soils of the study site for optimum plant growth.

The results of $\mathrm{P}$ concentration and uptake are in agreement with the finding of Mohanty et al. (2006), who reported that highest $\mathrm{P}$ content and uptake were observed in both groundnut and corn with organic fertilizer (poultry manure) as compared to single superphosphate application. The results of the soil analysis show (Table 1S) a low initial soil organic matter content $(<1 \%)$ which can limit the nutrient availability for plants, especially phosphorus. Therefore, applying a soil amendment, such as broiler litter, which has a high $\mathrm{P}$ content, can increase phosphorus availability in the soil along with increasing the carbon content. Demir et al. (2010) also showed that the application of poultry manure significantly increased available macronutrients (especially $\mathrm{P}$ and $\mathrm{N}$ ) in the soil and was one of the important reasons for optimum plant growth. They concluded that in the case of poultry manure, the $\mathrm{P}$ concentration increased due to the high $\mathrm{P}$ content in manure itself.

A higher total N-LER and P-LER in the AGDM and in the seeds were found in intercropping (especially with a higher share of fenugreek (fenugreek: buckwheat (2:1)), which indicates an advantage of a 
legume intercrop as compared to sole crops. This shows that one benefit of crops grown in association with fenugreek can also be measured in terms of the increased $\mathrm{N}$ and $\mathrm{P}$ concentration and uptake. Furthermore, the total N-LER and P-LER were considerably higher than unity across the IF and BL fertilizers in all intercropped treatments, indicating a nutrient yield advantage in AGDM at the flowering stage and in the seeds of fenugreek-buckwheat intercrops as compared to sole crops.

The enhanced soil $\mathrm{N}$ availability with fenugreek improved the nutrient use efficiency of the cropping system, these results corroborate with Dahmardeh and Hodiani (2016). ANUE and ANRE were higher in the fenugreek-buckwheat intercrops as compared to sole fenugreek and were furthermore higher with $\mathrm{CF}$ than with BL (as total applied $\mathrm{N}$ and not just assumed mineralized $50 \%$ for BL were taken into consideration for ANUE and ANRE calculations). The broiler litter and integrated fertilizer had higher soil residual $\mathrm{N}$ and $\mathrm{P}$ after harvest than the chemical fertilizer in 2014 (data not shown). Neugschwandtner and Kaul (2015) have shown that sowing ratio in intercrops and fertilization level can affect ANUE, in addition to factors such as sowing date and year (Neugschwandtner et al. 2015). The ANRE of sometimes more than $100 \%$ indicates that a high portion of the applied $\mathrm{N}$ was used and indicates that also some of the $\mathrm{N}$ taken up by plants was derived from mineralization processes in the soil or from $\mathrm{N}$ fixation. The higher ANRE in intercrops may also support the suggestion by Hauggaard-Nielsen et al. (2001) that crops grown in mixtures do not compete for the same resource niche and therefore are more efficient in their use of resources.

\section{Conclusions}

The application of both broiler litter alone and in an integrated fertilizer form (broiler litter with chemical fertilizer) was more effective in enhancing nutrient concentrations $\left(\mathrm{N}_{\mathrm{C}}\right.$ and $\left.\mathrm{P}_{\mathrm{C}}\right)$, nutrient uptake $\left(\mathrm{N}_{\mathrm{Up}}\right.$ and $\mathrm{P}_{\mathrm{Up}}$ ), yield and $\mathrm{N}$ and $\mathrm{P}$ land use advantages of fenugreek and buckwheat in both the sole and intercropped treatments at the flowering stage and of seed yields as compared to the chemical fertilizer application.

The N-LER and P-LER, applied $\mathrm{N}$ use efficiency and applied $\mathrm{N}$ recovery efficiency increased productivity of the intercrops (AGDM at flowering and seed yield) as compared to sole crops. For fenugreekbuckwheat intercrops, a higher share of fenugreek and lower share of buckwheat (2:1) appeared to be optimum for higher yield and nutrient advantage. Achievement of high yield and nutrient yield advantage in fenugreek and buckwheat by intercropping in semi-arid areas, through increasing the efficiency of nitrogen and phosphorus use, can minimize loss of these nutrients.

Acknowledgements Open access funding provided by University of Natural Resources and Life Sciences Vienna (BOKU). We are grateful to Shahrekord University for financial support of the experiments as well as to the University of Natural Resources and Life Sciences, Vienna (BOKU) for providing A. Salehi with a research opportunity.

Open Access This article is distributed under the terms of the Creative Commons Attribution 4.0 International License (http:// creativecommons.org/licenses/by/4.0/), which permits unrestricted use, distribution, and reproduction in any medium, provided you give appropriate credit to the original author(s) and the source, provide a link to the Creative Commons license, and indicate if changes were made. 


\section{Appendix}

See Tables 1 and 2.

Table 1 Pearson's correlation coefficients ( $r$ ) among macronutrients concentration, macronutrients uptake in individual above ground dry matter $\left(\mathrm{AGDM}_{\mathrm{P}}\right)$ and $\mathrm{AGDM}_{\mathrm{P}}$ at flowering, seed and seed yield at harvest of fenugreek in 2014 and 2015 ( $\mathrm{n}=36$ )

\begin{tabular}{|c|c|c|c|c|c|c|c|c|c|c|}
\hline \multirow[t]{2}{*}{2014} & & \multicolumn{5}{|c|}{$\mathrm{AGDM}_{\mathrm{P}}$ of fenugreek at flowering } & \multicolumn{4}{|c|}{ Seed of fenugreek } \\
\hline & & $\mathrm{N}_{\mathrm{C}}$ & $\mathrm{P}_{\mathrm{C}}$ & $\mathrm{AGDM}_{\mathrm{P}}$ & $\mathrm{N}_{\mathrm{up}}$ & $P_{\text {up }}$ & $\mathrm{N}_{\mathrm{C}}$ & $\mathrm{P}_{\mathrm{C}}$ & $\begin{array}{l}\text { Seed } \\
\text { yeild }\end{array}$ & $\mathrm{N}_{\mathrm{up}}$ \\
\hline \multirow{4}{*}{$\mathrm{AGDM}_{\mathrm{P}}$} & $\mathrm{P}_{\mathrm{C}}$ & $0.57^{* *}$ & & & & & & & & \\
\hline & $\mathrm{DM}$ & $-0.02^{\mathrm{ns}}$ & $0.13^{\mathrm{ns}}$ & & & & & & & \\
\hline & $\mathrm{N}_{\text {up }}$ & $0.18^{\mathrm{ns}}$ & $0.23^{\mathrm{ns}}$ & $0.98^{* * *}$ & & & & & & \\
\hline & $\mathrm{P}_{\text {up }}$ & $0.09^{\mathrm{ns}}$ & $0.33^{*}$ & $0.97^{* * *}$ & $0.97^{* * *}$ & & & & & \\
\hline \multirow{5}{*}{ Seed } & $\mathrm{N}_{\mathrm{C}}$ & $0.03^{\mathrm{ns}}$ & $0.25^{\mathrm{ns}}$ & $-0.12^{\mathrm{ns}}$ & $-0.15^{\mathrm{ns}}$ & $-0.09^{\text {ns }}$ & & & & \\
\hline & $\mathrm{P}_{\mathrm{C}}$ & $0.06^{\mathrm{ns}}$ & $0.25^{\mathrm{ns}}$ & $-0.13^{\text {ns }}$ & $-0.13^{\mathrm{ns}}$ & $-0.04^{\mathrm{ns}}$ & $0.28^{\mathrm{ns}}$ & & & \\
\hline & Seed yield & $0.21^{\mathrm{ns}}$ & $0.36^{*}$ & $0.90^{* * *}$ & $0.93^{* * *}$ & $0.92^{* * *}$ & $-0.13^{\mathrm{ns}}$ & $-0.14^{\mathrm{ns}}$ & & \\
\hline & $\mathrm{N}_{\text {up }}$ & $0.18^{\mathrm{ns}}$ & $0.42^{* *}$ & $0.87^{* * *}$ & $0.88^{* * *}$ & $0.91^{* * *}$ & $0.16^{\mathrm{ns}}$ & $-0.04^{\mathrm{ns}}$ & $0.95^{* * *}$ & \\
\hline & $\mathrm{P}_{\text {up }}$ & $0.23^{\mathrm{ns}}$ & $0.46^{* *}$ & $0.86^{* * *}$ & $0.88^{* * *}$ & $0.91^{* * *}$ & $-0.05^{\text {ns }}$ & $0.13^{\mathrm{ns}}$ & $0.96^{* * *}$ & $0.94^{* * *}$ \\
\hline \multirow[t]{2}{*}{2015} & & \multicolumn{5}{|c|}{$\mathrm{AGDM}_{\mathrm{P}}$ of fenugreek at flowering } & \multicolumn{4}{|c|}{ Seed of fenugreek } \\
\hline & & $\mathrm{N}_{\mathrm{C}}$ & $\mathrm{P}_{\mathrm{C}}$ & $\mathrm{AGDM}_{\mathrm{P}}$ & $\mathrm{N}_{\mathrm{up}}$ & $P_{\text {up }}$ & $\mathrm{N}_{\mathrm{C}}$ & $\mathrm{P}_{\mathrm{C}}$ & $\begin{array}{l}\text { Seed } \\
\text { yeild }\end{array}$ & $\mathrm{N}_{\text {up }}$ \\
\hline \multirow{4}{*}{$\mathrm{AGDM}_{\mathrm{P}}$} & $\mathrm{P}_{\mathrm{C}}$ & $0.69^{* * *}$ & & & & & & & & \\
\hline & $\mathrm{DM}$ & $-0.03^{\mathrm{ns}}$ & $-0.06^{\mathrm{ns}}$ & & & & & & & \\
\hline & $\mathrm{N}_{\text {up }}$ & $0.15^{\mathrm{ns}}$ & $0.06^{\mathrm{ns}}$ & $0.98^{* * *}$ & & & & & & \\
\hline & $\mathrm{P}_{\text {up }}$ & $0.07^{\mathrm{ns}}$ & $0.08^{\mathrm{ns}}$ & $0.99^{* * *}$ & $0.99^{* * *}$ & & & & & \\
\hline \multirow{5}{*}{ Seed } & $\mathrm{N}_{\mathrm{C}}$ & $-0.13^{\mathrm{ns}}$ & $-0.03^{\mathrm{ns}}$ & $-0.39^{*}$ & $-0.42^{*}$ & $-0.40^{*}$ & & & & \\
\hline & $\mathrm{P}_{\mathrm{C}}$ & $0.44^{* *}$ & $0.48^{* *}$ & $-0.06^{\mathrm{ns}}$ & $0.04^{\mathrm{ns}}$ & $0.01^{\mathrm{ns}}$ & $0.34^{*}$ & & & \\
\hline & Seed yield & $0.30^{\mathrm{ns}}$ & $0.79^{\mathrm{ns}}$ & $0.74^{* * *}$ & $0.76^{* * *}$ & $0.75^{* * *}$ & $-0.37^{*}$ & $0.08^{\mathrm{ns}}$ & & \\
\hline & $\mathrm{N}_{\text {up }}$ & $0.26^{\mathrm{ns}}$ & $0.19^{\mathrm{ns}}$ & $0.59^{* * *}$ & $0.61^{* * *}$ & $0.61^{* * *}$ & $0.07^{\mathrm{ns}}$ & $0.26^{\text {ns }}$ & $0.90^{* * *}$ & \multirow[b]{2}{*}{$0.87^{* * *}$} \\
\hline & $\mathrm{P}_{\text {up }}$ & $0.51^{* *}$ & $0.41^{*}$ & $0.59^{* * *}$ & $0.67^{* * *}$ & $0.65^{* * *}$ & $-0.16^{\mathrm{ns}}$ & $0.53^{* *}$ & $0.87^{* * *}$ & \\
\hline
\end{tabular}

${ }^{\mathrm{ns}}$ not significant

$*$, **, *** Significant effect at $p<0.05,0.01,0.001$, respectively 
Table 2 Pearson's correlation coefficients ( $r$ ) among macronutrients concentration, macronutrients uptake in individual above ground dry matter $\left(\mathrm{AGDM}_{\mathrm{P}}\right)$ and $\mathrm{AGDM}_{\mathrm{P}}$ at flowering stage, seed and seed yield at harvest of buckwheat in 2014 and 2015 (n = 36)

\begin{tabular}{|c|c|c|c|c|c|c|c|c|c|c|}
\hline \multirow[t]{2}{*}{2014} & & \multicolumn{5}{|c|}{$\mathrm{AGDM}_{\mathrm{P}}$ of buckwheat at flowering } & \multicolumn{4}{|c|}{ Seed of buckwheat } \\
\hline & & $\mathrm{N}_{\mathrm{C}}$ & $\mathrm{P}_{\mathrm{C}}$ & $\mathrm{AGDM}_{\mathrm{P}}$ & $\mathrm{N}_{\text {up }}$ & $\mathrm{P}_{\text {up }}$ & $\mathrm{N}_{\mathrm{C}}$ & $\mathrm{P}_{\mathrm{C}}$ & Seed yield & $\mathrm{N}_{\text {up }}$ \\
\hline & $\mathrm{P}_{\mathrm{C}}$ & $0.72^{* * *}$ & & & & & & & & \\
\hline & $\mathrm{DM}$ & $0.20^{\mathrm{ns}}$ & $0.04^{\mathrm{ns}}$ & & & & & & & \\
\hline & $\mathrm{N}_{\text {up }}$ & $0.43^{* *}$ & $0.21^{\mathrm{ns}}$ & $0.97^{* * *}$ & & & & & & \\
\hline & $\mathrm{P}_{\text {up }}$ & $0.45^{* *}$ & $0.45^{* *}$ & $0.90^{* * *}$ & $0.95^{* * *}$ & & & & & \\
\hline \multirow{5}{*}{ Seed } & $\mathrm{N}_{\mathrm{C}}$ & $0.32^{*}$ & $0.05^{\mathrm{ns}}$ & $0.02^{\mathrm{ns}}$ & $0.10^{\mathrm{ns}}$ & $0.05^{\mathrm{ns}}$ & & & & \\
\hline & $\mathrm{P}_{\mathrm{C}}$ & $0.43^{* *}$ & $0.09^{\mathrm{ns}}$ & $-0.05^{\mathrm{ns}}$ & $0.05^{\mathrm{ns}}$ & $-0.02^{\text {ns }}$ & $0.60^{* * *}$ & & & \\
\hline & Seed yield & $0.23^{*}$ & $0.02^{\mathrm{ns}}$ & $0.45^{* *}$ & $0.41^{*}$ & $0.37^{*}$ & $-0.48^{* *}$ & $-0.26^{\mathrm{ns}}$ & & \\
\hline & $\mathrm{N}_{\text {up }}$ & $0.25^{\mathrm{ns}}$ & $0.11^{\mathrm{ns}}$ & $0.47^{* *}$ & $0.48^{* *}$ & $0.43^{* *}$ & $0.07^{\mathrm{ns}}$ & $0.09^{\mathrm{ns}}$ & $0.82^{* * *}$ & \\
\hline & $\mathrm{P}_{\text {up }}$ & $0.23^{\mathrm{ns}}$ & $0.10^{\mathrm{ns}}$ & $0.42^{*}$ & $0.43^{* *}$ & $0.3^{*}$ & $-0.23^{\text {ns }}$ & $0.18^{\mathrm{ns}}$ & $0.90^{* * *}$ & $0.88^{* * *}$ \\
\hline \multirow[t]{6}{*}{2015} & & \multicolumn{5}{|c|}{$\mathrm{AGDM}_{\mathrm{P}}$ of buckwheat at flowering } & \multicolumn{4}{|c|}{ Seed of buckwheat } \\
\hline & & $\mathrm{N}_{\mathrm{C}}$ & $\mathrm{P}_{\mathrm{C}}$ & $\mathrm{AGDM}_{\mathrm{P}}$ & $\mathrm{N}_{\text {up }}$ & $\mathrm{P}_{\text {up }}$ & $\mathrm{N}_{\mathrm{C}}$ & $\mathrm{P}_{\mathrm{C}}$ & $\begin{array}{l}\text { Seed } \\
\text { yield }\end{array}$ & $\mathrm{N}_{\mathrm{up}}$ \\
\hline & $\mathrm{P}_{\mathrm{C}}$ & $0.68^{* * *}$ & & & & & & & & \\
\hline & $\mathrm{AGDM}_{\mathrm{P}}$ & $0.35^{*}$ & $0.28^{\mathrm{ns}}$ & & & & & & & \\
\hline & $\mathrm{N}_{\text {up }}$ & $0.42^{*}$ & $0.32^{*}$ & $0.99^{* * *}$ & & & & & & \\
\hline & $\mathrm{P}_{\text {up }}$ & $0.43^{* *}$ & $0.40^{*}$ & $0.99^{* * *}$ & $0.99^{* * *}$ & & & & & \\
\hline \multirow{5}{*}{ Seed } & $\mathrm{N}_{\mathrm{C}}$ & $0.20^{\mathrm{ns}}$ & $0.09^{\mathrm{ns}}$ & $-0.18^{\mathrm{ns}}$ & $-0.18^{\mathrm{ns}}$ & $-0.17^{\mathrm{ns}}$ & & & & \\
\hline & $\mathrm{P}_{\mathrm{C}}$ & $-0.09^{\mathrm{ns}}$ & $-0.32^{*}$ & $-0.98^{\mathrm{ns}}$ & $-0.10^{\mathrm{ns}}$ & $-0.13^{\text {ns }}$ & $0.38^{*}$ & & & \\
\hline & Seed yield & $0.37^{*}$ & $0.22^{\mathrm{ns}}$ & $0.82^{* * *}$ & $0.82^{* * *}$ & $0.82^{* * *}$ & $-0.06^{\text {ns }}$ & $-0.19^{\text {ns }}$ & & \\
\hline & $\mathrm{N}_{\text {up }}$ & $0.45^{* *}$ & $0.23^{\mathrm{ns}}$ & $0.63^{* * *}$ & $0.65^{* * *}$ & $0.63^{* * *}$ & $0.44^{* *}$ & $0.00^{\mathrm{ns}}$ & $0.86^{* * *}$ & \multirow[b]{2}{*}{$0.81^{* * *}$} \\
\hline & $\mathrm{P}_{\text {up }}$ & $0.29^{\mathrm{ns}}$ & $0.01^{\mathrm{ns}}$ & $0.71^{* * *}$ & $0.71^{* * *}$ & $0.68^{* * *}$ & $0.46^{\mathrm{ns}}$ & $0.40^{*}$ & $0.81^{* * *}$ & \\
\hline
\end{tabular}

${ }^{\mathrm{ns}}$ not significant

$*, * *, * * *$ Significant effect at $p<0.05,0.01,0.001$, respectively

\section{References}

Ahmad A, Alghamdi SS, Mahmood K, Afzal M (2016) Fenugreek a multipurpose crop: potentialities and improvements. Saudi J Biol Sci 23:300-310

Alamprese C, Casiraghi E, Pagani MA (2007) Development of gluten-free fresh egg pasta analogues containing buckwheat. Eur Food Res Technol 225:205-213

Alizadeh P, Fallah S, Raiesi F (2012) Potential N mineralization and availability to irrigated maize in a calcareous soil amended with organic manures and urea under field conditions. Int J Plant Prod 6:493-512

Bedoussac L, Justes E (2010) The efficiency of a durum wheatwinter pea intercrop to improve yield and wheat grain protein concentration depends on $\mathrm{N}$ availability during early growth. Plant Soil 330:19-35

Bremner JM (1996) Nitrogen-total. In: Sparks DL (ed) Methods of soil analysis, part 3. SSSA book ser. 5. SSSA and ASA, Madison, pp 1085-1121

Chandrashekara K, Somashekarappa HM (2016) Estimation of radionuclides concentration and average annual committed effective dose due to ingestion for some selected medicinal plants of South India. J Radiat Res Appl Sci 9(68-7):7

Chapagain T, Riseman A (2014) Barley-pea intercropping: effects on land productivity, carbon and nitrogen transformations. Field Crop Res 166:18-25
Dadrasan M, Chaichi MR, Pourbabaee AA, Yazdani D, Keshavarz-Afshar R (2015) Deficit irrigation and biological fertilizer influence on yield and trigonelline production of fenugreek. Ind Crop Prod 77:156-162

Dahmardeh M, Hodiani A (2016) Assessment of soil elements in intercropping based on mathematical modelling. Comput Electron Agric 122:218-224

Dai CC, Chen Y, Wang XX, Li PD (2013) Effects of intercropping of peanut with the medicinal plant Atractylodes lancea on soil microecology and peanut yield in subtropical China. Agrofor Syst 87:417-426

Damodar Reddy D, Subba Rao A, Rupa TR (2000) Effects of continuous use of cattle manure and fertilizer phosphorus on crop yields and soil organic phosphorus in a Vertisol. Bioresour Technol 75:113-118

Demir K, Sahin O, Kadioglu YK, Pilbeam DJ, Gunes A (2010) Essential and non-essential element composition of tomato plants fertilized with poultry manure. Sci Hortic 127:16-22

Dhima KV, Lithourgidis AS, Vasilakoglou IB, Dordas CA (2007) Competition indices of common vetch and cereal intercrops in two seeding ratio. Field Crop Res 100:249-256

Fallah S, Ghalavand A, Raiesi F (2013) Soil chemical properties and growth and nutrient uptake of maize grown with different combinations of broiler litter and chemical fertilizer in a calcareous soil. Commun Soil Sci Plant Anal $44: 3120-3136$ 
Fereidooni M, Raiesi F, Fallah S (2013) Ecological restoration of soil respiration, microbial biomass and enzyme activities through broiler litter application in a calcareous soil cropped with silage maize. Ecol Eng 58:266-277

Ghosh PK, Tripathi AK, Bandyopadhyay KK, Manna MC (2009) Assessment of nutrient competition and nutrient requirement in soybean/sorghum intercropping system. Eur J Agron 31:43-50

Hamzei J, Seyyedi M (2016) Energy use and input-output costs sunflower production in sole and intercropping with soybean under different tillage systems. Soil Till Res 157:73-82

Hauggaard-Nielsen H, Ambus P, Jensen ES (2001) Temporal and spatial distribution of roots and competition for nitrogen in pea-barley intercrops-a field study employing P-32 technique. Plant Soil 236:63-74

Hauggaard-Nielsen H, Gooding M, Ambus P, Corre-Hellou G, Crozat Y, Dahlmann C, Dibet A, Von Fragstein P, Pristeri A, Monti M, Jensen ES (2009a) Pea-barley intercropping for efficient symbiotic N2-fixation, soil $\mathrm{N}$ acquisition and use of other nutrients in European organic cropping systems. Field Crop Res 113:64-71

Hauggaard-Nielsen H, Gooding M, Ambus P, Corre-Hellou G, Crozat Y, Dahlmann C, Dibet A, Von Fragstein P, Pristeri A, Monti M, Jensen MES (2009b) Pea-barley intercropping and short-term subsequent crop effects across European organic cropping conditions. Nutr Cycl Agroecosyst 85:141-155

He YT, Zhang WJ, Xu MG, Tong XG, Sun FX, Wang JZ, Huang SM, Zhu P, He XH (2015) Long-term combined chemical and manure fertilizations increase soil organic carbon and total nitrogen in aggregate fractions at three typical cropland soils in China. Sci Total Environ 532:635-644

Iyamuremye F, Dick RP (1996) Organic amendments and phosphorus sorption by soils. Adv Agron 56:139-185

Jackson ML (1958) Soil chemical analysis. Prentice-Hall, Inc., Englewood Cliffs, pp 178-182

Jouzi Z, Azadi H, Taheri F, Zarafshani K, Gebrehiwot K, Van Passel S, Lebailly P (2017) Organic farming and smallscale sarmers: main opportunities and challenges. Ecol Econ 132:144-154

Kenny O, Smyth TJ, Hewage CM, Brunton NP (2013) Antioxidant properties and quantitative UPLC-MS analysis of phenolic compounds from extracts of fenugreek (Trigonella foenum-graecum) seeds and bitter melon (Momordica charantia) fruit. Food Chem 141:4295-4302

Mead R, Willey RW (1980) The concept of land equivalent ratio and advantages in yield from intercropping. Exp Agric 16:217-218

Meade G, Lalorb STJ, Mc Cabea T (2011) An evaluation of the combined usage of separated liquid pig manure and inorganic fertiliser in nutrient programmes for winter wheat production. Eur J Agron 34:62-70

Mohanty S, Paikaray NK, Rajan AR (2006) Availability and uptake of phosphorus from organic manures in groundnut (Arachis hypogea L.)-corn (Zea mays L.) sequence using radio tracer technique. Geoderma 133:225-230

Musa M, Leitch MH, Iqbal M, Sahi FUH (2010) Spatial arrangement affects growth characteristics of barley-pea intercrops. Int J Agric Biol 12:685-690
Neugschwandtner RW, Kaul H-P (2014) Sowing ratio and N fertilization affect yield and yield components of oat and pea in intercrops. Field Crop Res 155:159-163

Neugschwandtner RW, Kaul H-P (2015) Nitrogen uptake, use and utilization efficiency by oat-pea intercrops. Field Crop Res 179:113-119

Neugschwandtner RW, Kaul H-P (2016) Concentrations and uptake of macronutrients by oat and pea in intercrops in response to $\mathrm{N}$ fertilization and sowing ratio. Arch Agron Soil Sci 62:1236-1249

Neugschwandtner RW, Böhm K, Hall RM, Kaul H-P (2015) Development, growth, and nitrogen use of autumn- and spring-sown facultative wheat. Acta Agric Scand Sect B 65:6-13

Oelbermann M, Echarte L (2011) Evaluating soil carbon and nitrogen dynamics in recently established maize-soyabean inter-cropping systems. Eur J Soil Sci 62:35-41

Osman AE, Nersoyan N (1986) Effect of the proportion of species on the yield and quality of forage mixtures, and on the yield of barley in the following year. Exp Agric 22:345-351

Rostaei M, Fallah S, Abbasi Sorki A (2014) Effect of fertilizer sources on growth, yield and yield components of fenugreek intercropped with black cumin. J Crop Prod 7:197-222

Ruby BC, Gaskill SE, Slivka D, Harger SG (2005) The addition of fenugreek extract (Trigonella foenum-graecum) to glucose feeding increases muscle glycogen resynthesis after exercise. Amino Acids 28:71-76

Sahota TS, Malhi SS (2012) Intercropping barley with pea for agronomic and economic considerations in northern Ontario. Agric Sci 3(7):889-895

Salehi A, Fallah S, Kaul H-P (2016) Broiler litter and inorganic fertilizer effects on seed yield and productivity of buckwheat and fenugreek in row intercropping. Arch Agron Soil Sci. https://doi.org/10.1080/03650340.2016.1258114

Saxena A, Vikram NK (2004) Role of selected Indian plants in management of type 2 diabetes: a review. J Altern Complement Med 10:369-378

Scalise A, Tortorella D, Pristeri A, Petrovičová B, Gelsomino A, Lindström K, Monti M (2015) Legume-barley intercropping stimulates soil $\mathrm{N}$ supply and crop yield in the succeeding durum wheat in a rotation under rainfed conditions. Soil Biol Biochem 89:150-161

Tejada M, Benitez C, Parrado J (2011) Application of biostimulants in benzo(a)pyrene polluted soils: short-time effects on soil biochemical properties. Appl Soil Ecol 50:21-26

Yan ZJ, Liu PP, Li YH, Ma L, Alva A, Dou ZX, Chen Q, Zhang FS (2013) Phosphorus in China's intensive vegetable production systems: over-fertilization, soil enrichment, and environmental Implications. J Environ Qual 42:982-989

Yan S, Du X, Wu F, Li L, Li C, Meng Z (2014) Proteomics insights into the basis of interspecific facilitation for maize (Zea mays) in faba bean (Vicia faba)/maize intercropping. J Proteomics 109:111-124

Yan Z, Chen S, Li J, Alva A, Chen Q (2016) Manure and nitrogen application enhances soil phosphorus mobility in calcareous soil in greenhouses. J Environ Manag 181:26-35 